\title{
Article
}

\section{PTD4 Peptide Increases Neural Viability in an In Vitro Model of Acute Ischemic Stroke}

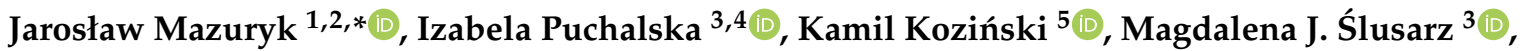 \\ Jarosław Ruczyński ${ }^{3}{ }^{\circ}$, Piotr Rekowski ${ }^{3}{ }^{\circ}$, Piotr Rogujski ${ }^{1,6}{ }^{\circ}$, Rafał Płatek ${ }^{1,7}{ }^{\circ}$, Marta Barbara Wiśniewska ${ }^{5}{ }^{\circ}$, \\ Arkadiusz Piotrowski ${ }^{8}{ }^{\circ}$, Łukasz Janus ${ }^{9}$, Piotr M. Skowron ${ }^{3}{ }^{\circ}$, Michał Pikuła ${ }^{10}{ }^{\circ}$, Paweł Sachadyn ${ }^{7}$, \\ Sylwia Rodziewicz-Motowidło ${ }^{3}$ (I) , Artur Czupryn ${ }^{1}$ (I) and Piotr Mucha ${ }^{3, *}$ (D)
}

check for updates

Citation: Mazuryk, J.; Puchalska, I.; Koziński, K.; Ślusarz, M.J.; Ruczyński, J.; Rekowski, P.; Rogujski, P.; Płatek,

R.; Wiśniewska, M.B.; Piotrowski, A.; et al. PTD4 Peptide Increases Neural Viability in an In Vitro Model of Acute Ischemic Stroke. Int. J. Mol. Sci. 2021, 22, 6086. https://doi.org/ $10.3390 /$ ijms 22116086

Academic Editor: Cesar Borlongan

Received: 30 April 2021

Accepted: 30 May 2021

Published: 4 June 2021

Publisher's Note: MDPI stays neutral with regard to jurisdictional claims in published maps and institutional affiliations.

Copyright: (c) 2021 by the authors. Licensee MDPI, Basel, Switzerland. This article is an open access article distributed under the terms and conditions of the Creative Commons Attribution (CC BY) license (https:/ / creativecommons.org/licenses/by/ $4.0 /)$.
1 Laboratory of Neurobiology, Nencki Institute of Experimental Biology PAS, 02-093 Warsaw, Poland; progujski@imdik.pan.pl (P.R.); rafal.platek@pg.edu.pl (R.P.); a.czupryn@nencki.edu.pl (A.C.)

2 Department of Electrode Processes, Institute of Physical Chemistry, Polish Academy of Sciences, Kasprzaka 44/52, 01-224 Warsaw, Poland

3 Faculty of Chemistry, University of Gdańsk, Wita Stwosza 63, 80-308 Gdańsk, Poland; izabelapuchalska8@gmail.com (I.P.); magdalena.slusarz@ug.edu.pl (M.J.Ś.); jaroslaw.ruczynski@ug.edu.pl (J.R.); piotr.rekowski@ug.edu.pl (P.R.); piotr.skowron@ug.edu.pl (P.M.S.); s.rodziewicz-motowidlo@ug.edu.pl (S.R.-M.)

4 Institute of Biotechnology and Molecular Medicine, 80-172 Gdańsk, Poland

5 Laboratory of Molecular Neurobiology, Centre of New Technologies, University of Warsaw, 02-097 Warsaw, Poland; k.kozinski@cent.uw.edu.pl (K.K.); m.wisniewska@cent.uw.edu.pl (M.B.W.)

6 NeuroRepair Department, Mossakowski Medical Research Institute PAS, 02-106 Warsaw, Poland

7 Laboratory for Regenerative Biotechnology, Gdańsk University of Technology, 80-233 Gdańsk, Poland; psach@pg.edu.pl

8 Department of Biology and Pharmaceutical Botany, Faculty of Pharmacy, Medical University of Gdańsk, 80-416 Gdańsk, Poland; arpiotr@gumed.edu.pl

9 MedVentures Company, 60-141 Poznań, Poland; j.medventures@gmail.com

10 Laboratory of Tissue Engineering and Regenerative Medicine, Department of Embryology, Medical University of Gdańsk, 80-210 Gdańsk, Poland; pikula@gumed.edu.pl

* Correspondence: jmazuryk@ichf.edu.pl (J.M.); piotr.mucha@ug.edu.pl (P.M.); Tel.: +48-22-343-2094 (J.M.); +48-58-523-5432 (P.M.)

Abstract: Ischemic stroke is a disturbance in cerebral blood flow caused by brain tissue ischemia and hypoxia. We optimized a multifactorial in vitro model of acute ischemic stroke using rat primary neural cultures. This model was exploited to investigate the pro-viable activity of cell-penetrating peptides: arginine-rich Tat(49-57)- $\mathrm{NH}_{2}$ ( ${ }^{49} \mathrm{KKRRQRRR}^{57}$-amide) and its less basic analogue, PTD4 ( $\mathrm{Y}^{47}$ ARAAARQARA ${ }^{57}$-amide). Our model included glucose deprivation, oxidative stress, lactic acidosis, and excitotoxicity. Neurotoxicity of these peptides was excluded below a concentration of $50 \mu \mathrm{m}$, and PTD4-induced pro-survival was more pronounced. Circular dichroism spectroscopy and molecular dynamics (MD) calculations proved potential contribution of the peptide conformational properties to neuroprotection: in $\mathrm{MD}$, Tat(49-57)- $\mathrm{NH}_{2}$ adopted a random coil and polyproline type II helical structure, whereas PTD4 adopted a helical structure. In an aqueous environment, the peptides mostly adopted a random coil conformation (PTD4) or a polyproline type II helical (Tat(4957)- $\mathrm{NH}_{2}$ ) structure. In 30\% TFE, PTD4 showed a tendency to adopt a helical structure. Overall, the pro-viable activity of PTD4 was not correlated with the arginine content but rather with the peptide's ability to adopt a helical structure in the membrane-mimicking environment, which enhances its cell membrane permeability. PTD4 may act as a leader sequence in novel drugs for the treatment of acute ischemic stroke.

Keywords: arginine-rich peptides; cell-penetrating peptides; excitotoxicity; ischemic stroke; neural viability; neuroprotection; neurotoxicity; peptide conformation; PTD4; Tat(49-57)- $\mathrm{NH}_{2}$ 


\section{Introduction}

Stroke is characterized as an acute pathological decrease in blood flow in the brain, which lasts longer than $24 \mathrm{~h}$ and often leads to neurological deficits or death. Acute ischemic stroke (AIS) accounts for $87 \%$ of stroke cases and is a leading cause of disability and death worldwide [1,2]. In 2017, stroke-related health care cost 32 European countries around $€ 60$ billion [3]. At the cellular level, the complex pathophysiology of AIS mainly involves excitotoxicity and inflammation $[4,5]$. In detail, the excitotoxicity follows primary events that occur upon the disruption of the blood-brain barrier, i.e., nutrient deprivation and acute hypoxia. These malfunctions are also associated with uncontrolled depolarization of membrane potential and mitochondrial dysregulation, causing cellular respiration impediment and deviated aerobic glycolysis, and leading to lactic acidosis. The ultimate outcome of this morbid cascade is an irreversible loss of neuronal function along with neuronal death.

Minimization or reversion of deleterious AIS impacts on neurons, ascribed to postischemic neuroprotection, is a pharmacological challenge. Currently, the only available AIS treatment strategy is re-establishing perfusion through the obstructed blood vessels with pharmacologic or mechanical thrombolysis. Thus far, intravenous administration of recombinant serine protease tissue-type plasminogen activator (rtPA), i.e., the only FDA-approved drug for AIS, has its intrinsic limitations such as a short therapeutic time window (about $4.5 \mathrm{~h}$ from the incident of stroke) and the unavoidable risk of subsequent hemorrhage [6,7].

One of the most recent approaches to reduce AIS-related neuronal death is the application of cell-penetrating peptides (CPPs) as neuroprotective agents. CPPs have emerged as a powerful medicine tool owing to their exceptional ability to cross cell membranes [8,9]. The era of CPPs in biomedicine originated with the discovery of the trans-activator of transcription HIV-1 Tat protein [10,11]. The unusual activity of the CPPs is endowed by the Tat transduction domain (PTD), the arginine-rich motif (ARM, amino acids 49-57), a uniquely evolved retroviral protein module [12]. The PTD is a blood-brain barrier (BBB) shuttle peptide with an intrinsic membrane crossing activity that facilitates the cargo translocation across an intact BBB [13,14]. Moreover, the PTD-mediated translocation through the cell membrane has been shown to depend on the arginine content of the PTD and other arginine-rich peptides (RRPs), i.e., a group of peptides possessing size from 4 to 40 amino acids, positive net charge $(+2$ to +20$)$, one or more positively charged arginine residues that comprise from 20 to $100 \%$ of the peptide, as well as other positively charged amino acids $[15,16]$. Sequence modifying studies demonstrated that cell membrane translocation of PTD4 peptide, which has a lower number of arginine residues than Tat $(49-57)[17,18]$, was accomplished more preferably than in the case of the latter $[19,20]$. (Table 1).

Table 1. Physicochemical properties of peptides studied ( ${ }^{*}$ asymmetrical dimethylation).

\begin{tabular}{|c|c|c|c|c|}
\hline Peptide & Sequence & Remarks & $\begin{array}{c}\text { Molecular Weight } \\
\text { [g/mol] }\end{array}$ & $\begin{array}{l}\text { Net Chargeat } \\
\text { pH 7.0 }\end{array}$ \\
\hline Tat(49-57)- $\mathrm{NH}_{2}$ & $\mathrm{RKKR}^{52} \mathrm{RQRRR}^{57}$-amide & Native sequence & 1338.62 & 9 \\
\hline DR52 & RKKrRQRRR-amide & & 1338.62 & 9 \\
\hline Tat6s & Ac-RRQRRR-amide & Ac-Tat(52-57)-NH $\mathrm{NH}_{2}$ & 968.13 & 5 \\
\hline Tat7s & Ac-R(Me $)_{2} R Q R R R$-amide (ASDM) * & $\mathrm{Ac}-\left[\mathrm{Arg}(\mathrm{Me})_{2}\right] \operatorname{Tat}(52-57)-\mathrm{NH}_{2}$ & 996.13 & 5 \\
\hline PTD4 & YARAAARQARA-amide & & 1203.36 & 4 \\
\hline Prop-Tat & propiolyl-RKKRRQRRR ${ }^{57}$-amide & Prop-Tat(49-57)- $\mathrm{NH}_{2}$ & 1390.62 & 8 \\
\hline TP10 & AGYLLGKINLKẪAALAKKIL-amide & & 2181.75 & 5 \\
\hline
\end{tabular}

This remarkable feature of the RPPs was thrivingly encompassed in the cellular delivery of neuroprotective cargoes [21]. Along with the pronounced arginine-content influence on the cellular permeability potency of the RRPs, it strongly correlates with neuroprotective activity. In a series of studies, it was shown that exceeding the optimal arginine residues number may attenuate pro-viable activity $[5,22,23]$. Moreover, neurotoxicity of specific Tat peptides and full-length native HIV-1 Tat protein was also reported as approximately $15-50 \%$ of HIV-infected patients suffer from HIV-associated neurocognitive disorders (HAND), 
dementia, mild or asymptomatic neurocognitive impairment, and encephalitis [24,25]. Because the neurotoxicity mechanism of Tat peptides differs significantly from that of HIV-1 Tat protein, comprehensive studies of Tat peptides' impact on neural cells appears as a matter of paramount importance.

Tat(49-57)- $\mathrm{NH}_{2}$ is commonly used in neuroscience as a selective cell-penetrating transporter $[21,26,27]$. Classic studies demonstrated that Tat peptides' neuroprotection strongly depends on their electrostatic and conformational properties [5,16,28]. More recently, however, the idea that the ability of a peptide to exert neuroprotection depends on its potential to penetrate the neuronal membrane began to prevail [29]. Although several parameters are essential for this internalization mechanism, recent focuses suggest that conformational interactions with membrane phospholipids play a crucial role during cellular uptake [30].

The therapeutic potential of RRPs for reversing AIS symptoms has emerged from the screening of neuroprotective drugs capable of the immediate preservation of neurons in the ischemia-stricken brain. Thus far, vast and convincing data demonstrate this propensity for RRPs. Moreover, these pro-viability merits were matched with the net charge of the RRPs $[5,22,28]$. It was clearly proved that the high cationic charge enables electrostatic binding of the arginine guanidinium groups with heparan sulphate proteoglycans, sialic acid residues on glycosphingolipids, or phosphate head groups present in membrane phospholipids [5,31]. Furthermore, this capacity's effectiveness enhances with increasing peptide length, the number of arginine residue, and net charge, wherewith 15 arginine residues provide maximal efficacy $[5,22,23]$. In physiological conditions, this mechanism not only impacts the neuronal endocytic progression and endosomal peptide transduction but also stimulates the internalization of cell surface ion channels and receptors. This, in turn, decreases intracellular calcium ion influx and the risk of fatal excitotoxicity [31].

Various in vitro models of AIS have been established in the recent decade [32]. Most common platforms refer to brain microvascular endothelial cells [33], implemented with astrocytes and pericytes [34], extracellular matrix components [35], or associated with circulating immune cells [36]. Other models involve primary neuronal-astrocytic cultures [37], embryonic stem cells [38], induced pluripotent stem cells [39], and human conditionally immortalized neural stem cells [40].Future studies shall focus on 3D co-cultures seeded on hydrogel scaffolds and biomatrices [41] or cultivated in microfluidic systems [42]. These sophisticated models enable physiologically relevant and multi-level in vitro studies on energy depletion, excitotoxicity, inflammation, and drug delivery to AIS [32]. On the other hand, due to complexed structures, ethical issues, and expensive and labor-consuming fabrication, these models are hardly useful for high-throughput drug screening, drug-cell interaction studies, and pre-clinical trials [32,43].

For this motif, in the present study, we used a simple model of primary neural cells to investigate the relationship between basicity, secondary structure, and pro-viable activity of Tat peptides. We then used a multifactorial in vitro model of AIS and a series of Tat analogues to test which of these parameters affects neuroprotection of the peptides. We demonstrated that the PTD4 peptide displays higher protective activity than the Tat(49-57)$\mathrm{NH}_{2}$ peptide, suggesting that conformational features of these peptides and their ability to translocate through the cell membrane, rather than the arginine content and a positive net charge, indicate their ameliorating capability of neural viability preservation.

\section{Results}

\subsection{Ala-Substitution Favors Helicity of PTD4 Compared to Tat(49-57)- $\mathrm{NH}_{2}$}

In general, arginine-rich peptides such as Tat(49-57) cannot adopt a helical structure [44]. In aqueous solutions, the polyarginine peptides form unstructured [45] or polyproline type II helical conformations [46-48]. Most likely, this phenomenon results from a strong repulsive interaction between the quinidine groups of the arginine residues. As already demonstrated, modeling the Tat's ARM structure in order to obtain the most stable helical conformation has led to the design of the PTD4 peptide (see Figure 1), in 
which the replacement of particular arginine residues by alanine residues resulted in a Tat(49-57)- $\mathrm{NH}_{2}$ analogue with enhanced membrane transduction potential [45].

A.

10

30

40

50

MEPVDPRLEP WKHPGSQPKT ACTNCYCKKC CFHCQVCFIT KALGISYGRK

60

70

80

\title{
KRRQRRRAHQ NSQTHQASLS KQPTSQPRGD PTGPKE
}

\author{
B. $\quad \mathrm{R}^{49} \underline{\mathrm{KKRRQR}} \underline{\underline{R}^{57}}-\mathrm{NH}_{2}$ \\ C. $\quad \mathrm{Y}^{47} \mathrm{AR}^{49} \mathrm{AAARQARA}{ }^{57}-\mathrm{NH}_{2}$ \\ sequence homology
}

Figure 1. (A) Amino acid sequences of the "canonical" variant of HIV-1 Tat (P04608-1 identifier of the UniProt database), (B) Tat(49-57)- $\mathrm{NH}_{2}$ with underlined Ala-substituted residues, and (C) PTD4. Asterisks (*) indicate positions of sequence homology (R, R, Q, R).

In order to verify how conformational structures of the peptides impact their potential to cross the cell membrane, we inquired whether a replacement of Arg with Ala amino acid residues increases the peptides' helicity. The influence of this Ala-substitution on the conformational properties of the Tat(49-57)- $\mathrm{NH}_{2}$ and PTD4 peptides was evaluated by $\mathrm{CD}$ spectroscopy. The $\mathrm{CD}$ spectra of Tat(49-57)- $\mathrm{NH}_{2}$ aqueous solutions revealed distinct polyproline type II conformations (Figure 2 ). The $\mathrm{CD}$ spectrum presented a strong negative minimum at $\lambda \approx 195 \mathrm{~nm}$ and an additional maximum at $\lambda \approx 215 \mathrm{~nm}$. In contrast, the CD spectra of PTD4 possessed a weak minimum at $\lambda \approx 195 \mathrm{~nm}$ with an additional wide maximum at $\lambda \approx 220 \mathrm{~nm}$, characterized by lower intensity and increased width compared to those of Tat(49-57)- $\mathrm{NH}_{2}$. This indicated a more unstructured (random coil) conformation of PTD4 compared to Tat(49-57)- $\mathrm{NH}_{2}$. Together, these outcomes presented the effect of the Ala-substitution procedure on the conformational properties of Tat(49-57)- $\mathrm{NH}_{2}$. 


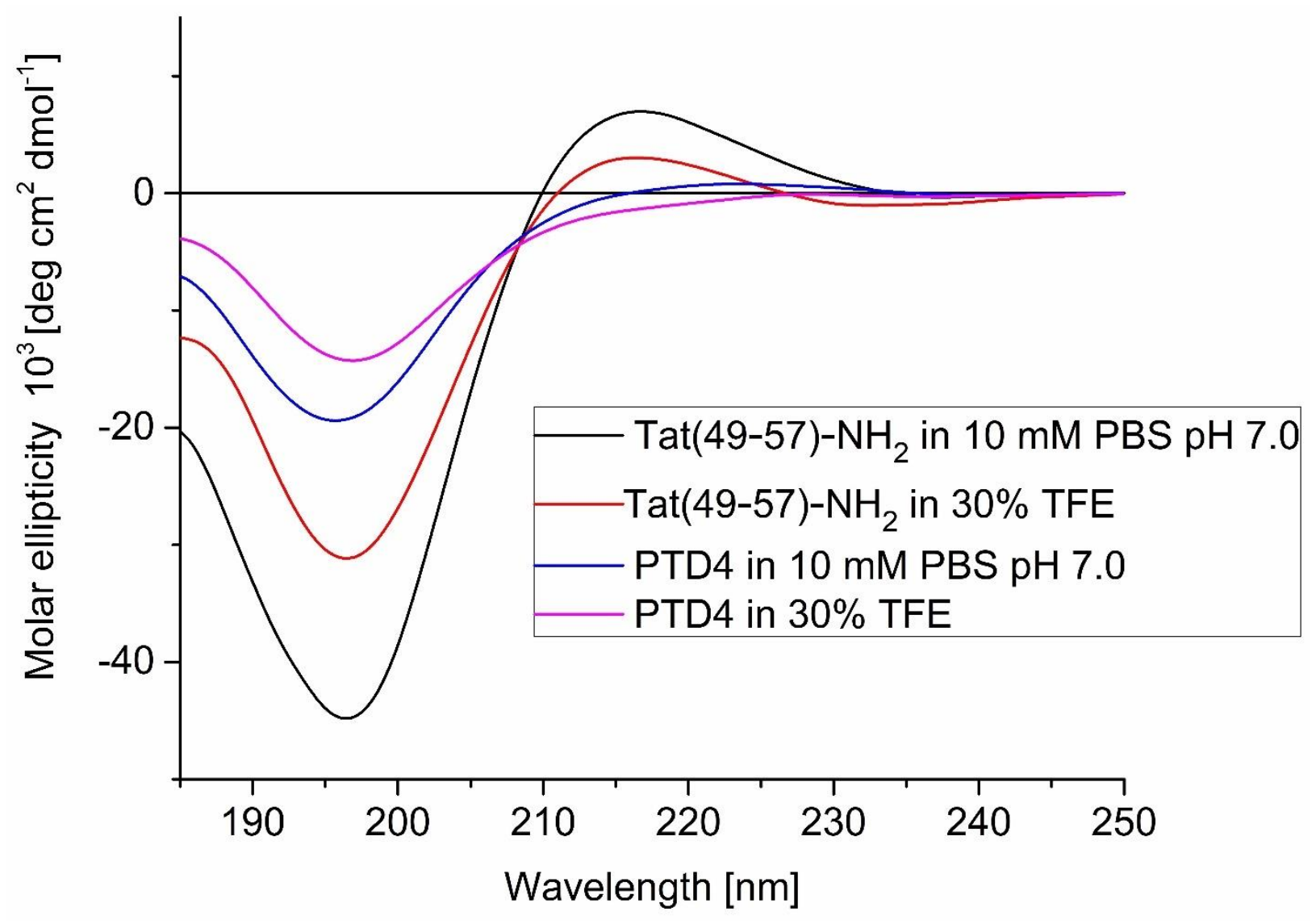

Figure 2. CD spectra of Tat(49-57)- $\mathrm{NH}_{2}$ and PTD4 peptides in $10 \mathrm{mM}$ PBS, pH 7.0 and 30\% (v/v) TFE.

\subsection{Conformational Structure of PTD4 Predisposes It to Enter the Cell Interior}

Since the peptide conformation-based interactions with the cell membrane or membrane receptors may contribute to CPP pro-viable properties, we compared conformational behaviors of Tat(49-57)- $\mathrm{NH}_{2}$ and PTD4 peptides in 30\% (v/v) TFE solution, which is an excellent alpha-helix inducer and, as such, may mimic the hydrophobic interior of the cell membrane $[49,50]$. In this condition, peptides tend to adopt a stable secondary, mainly helical, conformation that predisposes them for natural conformational behavior $[17,18,51,52]$. TFE-induced folding processes in the peptide structures were analyzed by CD spectroscopy. The CD spectra of Tat(49-57)- $\mathrm{NH}_{2}$ and PTD4 peptides displayed negative maxima at $\lambda \approx 195 \mathrm{~nm}$. However, a significant difference in intensity of molar ellipticity was observed compared to spectra acquired in aqueous solutions. In the case of Tat(49-57)- $\mathrm{NH}_{2}$, a significant intensity decrease of a positive maximum at $\lambda \approx 215 \mathrm{~nm}$ was also observed. Regarding PTD4, the shallow maximum at $\lambda \approx 225 \mathrm{~nm}$ was no longer visible and was replaced by a shallow, weakly scratched minimum at $\lambda \approx 225 \mathrm{~nm}$. In contrast, Tat(49-57)- $\mathrm{NH}_{2}$ exhibited a shallow positive maximum at this wavelength. The CD spectra recorded in 30\% TFE showed evident conformational changes compared to those recorded in an aqueous solution. This indicated that for Tat(49-57)- $\mathrm{NH}_{2}$ the content of type II polyproline helix structure decreased and the random-coil content increased, whereas, for the PTD4 peptide, a small minimum at $\lambda \approx 225 \mathrm{~nm}$ indicated the formation of an $\alpha$-helical conformation. These structural differences predispose PTD 4 to penetrate the cell interior more effectively than Tat(49-57)- $\mathrm{NH}_{2}$.

\subsection{PTD4 Adopts the Favorable Structure in the Membrane-Mimicking Environment}

To confirm structural differences between PTD4 and Tat(49-57)- $\mathrm{NH}_{2}$, we calculated molecular dynamics (MD) with no constraints for both peptides in water and 30\% TFE. Afterwards, in the 100 ns-long dynamics simulations in the AMBER full-atomic force field, 
the structures were divided into 10 clusters (see Figure S1a,b for water and Figure S1c,d for 30\% TFE, respectively; see Supplementary Materials). The percentage of molecules in each cluster is presented in Figure S1. As observed, cluster 1 (cluster with the largest conformation population) and cluster 2 (cluster with the second-largest conformation population, see Figure S1) occurred as the most abundant and summed up to $\sim 60 \%$ of all conformations.

Representative structures obtained for these dominant clusters are presented in Figure S1. In both solvents, Tat(49-57)- $\mathrm{NH}_{2}$ formed mainly a disordered conformation (cluster 1) and classic type II polyproline helix (cluster 2). As shown in Figure 3A,C, the positively charged amino acid residues extruded out the Tat(49-57)- $\mathrm{NH}_{2}$ peptide due to strongly repulsive positive charges present on the side chains. As a result, the Arg and Lys residues were mostly located on the other two sides of the type II polyproline helix. Hence, this adopted spatial disposition was suitable for interaction with the cell membrane in the first step of peptide internalization [53,54]. In contrast, the PTD4 peptide also displayed a disordered conformation (cluster 1) but with a slight tendency to form the helical structure in the Ala4-Gln8 region (cluster 2). In 30\% TFE though, the PTD4 peptide exhibited a more pronounced tendency towards the helical structure formation. In this condition, in cluster 1 the helix was formed in the Ala5-Arg10 region, whereas in cluster 2 the formation of the helix was in the Arg3-Ala9 region. These analyses demonstrated that in the hydrophobic, membrane-mimicking environment, such as 30\% TFE solution, PTD4 adopted the helical conformation (Figure 3D), characterized by an arginine residue stack present on the same side of the helix. Since a helical conformation and an increased arginine content in the peptide enhance its translocation through the cell membrane, it is expected that PTD4 will effectively interact with the neuronal membrane. Future investigations using other membrane mimetics, such as sodium dodecyl sulphate, and small or large unilamellar vesicles, or lipid bilayers, shall reveal details of the PTD4 secondary structure and its behavior upon contact with the cell membrane.

A)

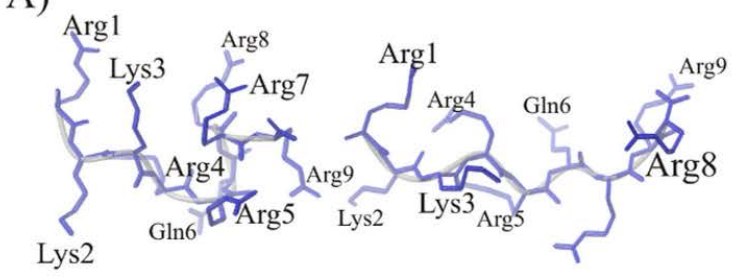

C)

$\operatorname{Arg} 7$
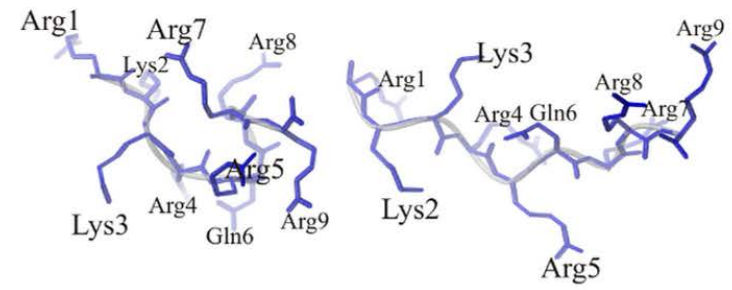

B)

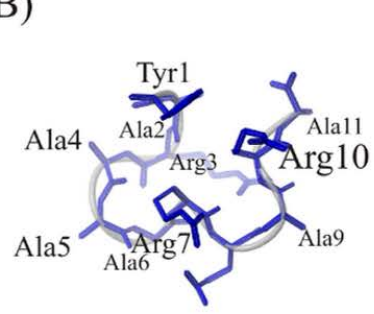

D)

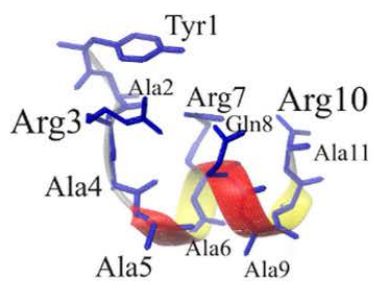

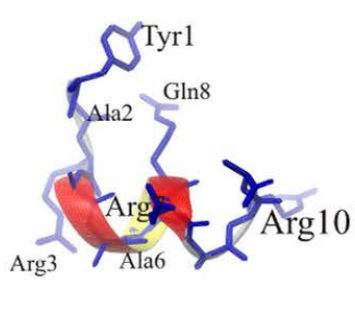

Ala9

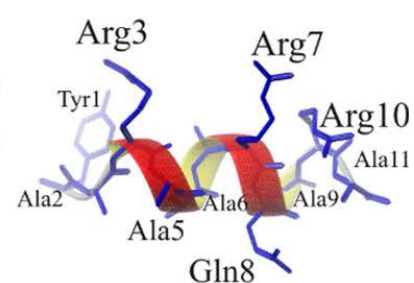

Figure 3. Spatial structures of the two most dominant clusters calculated for Tat(49-57)- $\mathrm{NH}_{2}$ in water (A) and 30\% TFE (C), and for PTD4 in water (B) and 30\% TFE (D). On the left, cluster 1; on the right, cluster 2.

\subsection{PTD4 Expresses no or Minor Neurotoxicity in Primary Neural Cortical Cultures}

Being a CPP/RRP group member, Tat(49-57)- $\mathrm{NH}_{2}$ expresses ambiguous activity in terms of its influence on neuronal metabolism and signal trafficking within the brain [23]. Hence, pharmacological application of Tat(49-57)- $\mathrm{NH}_{2}$, either as a drug delivery system or a stand-alone neuroprotective agent, would require strict control in both dose-dependent and spatio-temporal manners. Despite the well-documented inherent neuroprotection of 
RRPs, special attention must be paid to their neurotoxic activities. What is more, $C$-terminal amidation may increase the neuroprotective effect of the peptide, whereas, conversely, $\mathrm{N}$-terminal acetylation generally decreases it, as was shown for Arg9 peptide [55]. The neurotoxic influence of these post-translational modifications (PTMs) was proven to be dose-dependent and, basically, to enhance peptide stability against enzymatic proteolysis in physiological conditions [56]. Similarly, an ameliorating effect was observed upon the position-specific D-stereoisomerization of CPPs [57]. Comprehensive studies have demonstrated that the D-amino acid-bearing CPPs display higher protease resistance [58] and undergo facilitated cell type-dependent internalization [59]. The effectiveness of the cell entry has been reported to depend upon the number of D-arginine residues in CPPs [60]. Finally, alkylation of CPPs has also been demonstrated to enhance their performance [44]. Such modification of CPPs may change its translocation through the cell membrane or the specificity of membrane receptor recognition [61,62]. These, in turn, may cause peptide neurotoxicity or neuroprotection. To verify these aspects with regard to Tat RRPs, a series of Tat analogues were synthesized (Table 1), and their neurotoxicity was assessed in primary neural cultures (Figures 4-6). Apart from Tat(49-57)- $\mathrm{NH}_{2}$ and PTD4, the following modifications were analyzed: $\mathrm{N}$-acetylation (Tat6), arginine methylation (Tat7), $\mathrm{N}$ - propiolylation (Prop-Tat), and D-Arg substitution (DR52). Besides, we analyzed TP10 peptide, a commonly used CPP [9], that does not bear amino-acid sequence homology to Tat(49-57)- $\mathrm{NH}_{2}$. This set of analogues contains typical PTMs that diversify these peptides with regard to the net charge and hydrophobicity, and conceivably, with regard to neuroactivity. Prop-Tat analogue was included in this series to characterize the neurotoxicity of the alkyne-bearing component of click-chemistry reaction.

\section{A. ASSESSMENT OF PEPTIDE NEUROTOXICITY}

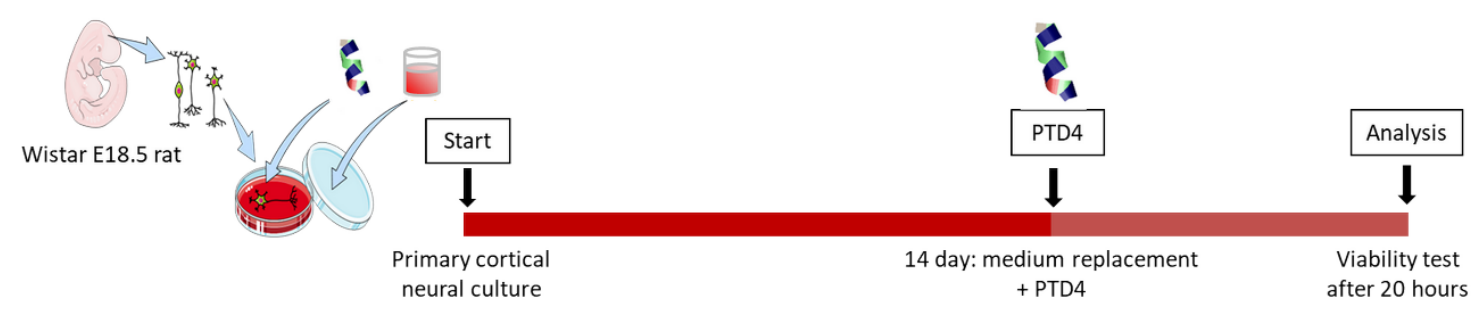

B. MODEL OF ACUTE ISCHEMIC STROKE (AIS)
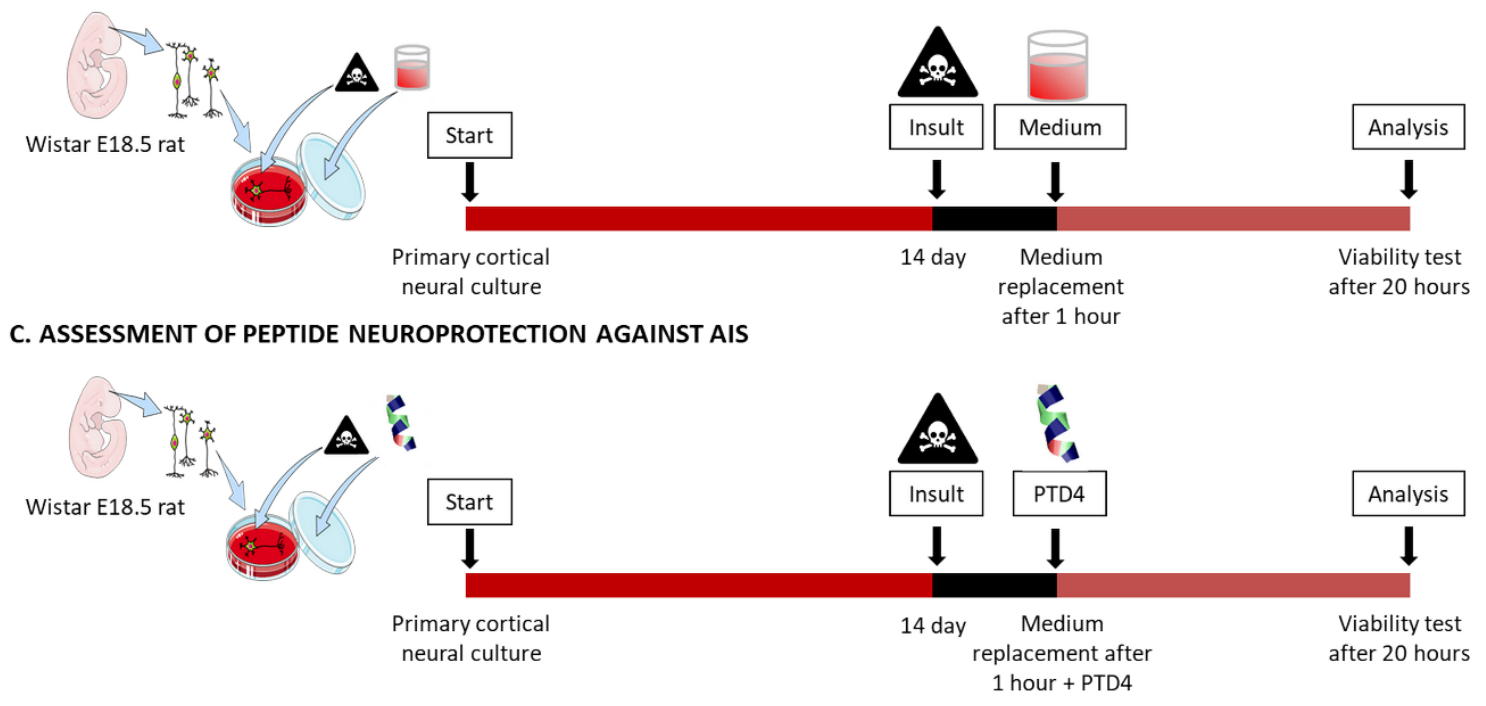

Figure 4. Experimental designs: peptide neurotoxicity (A), in vitro model of AIS (B), and peptide neuroprotection against AIS (C). 


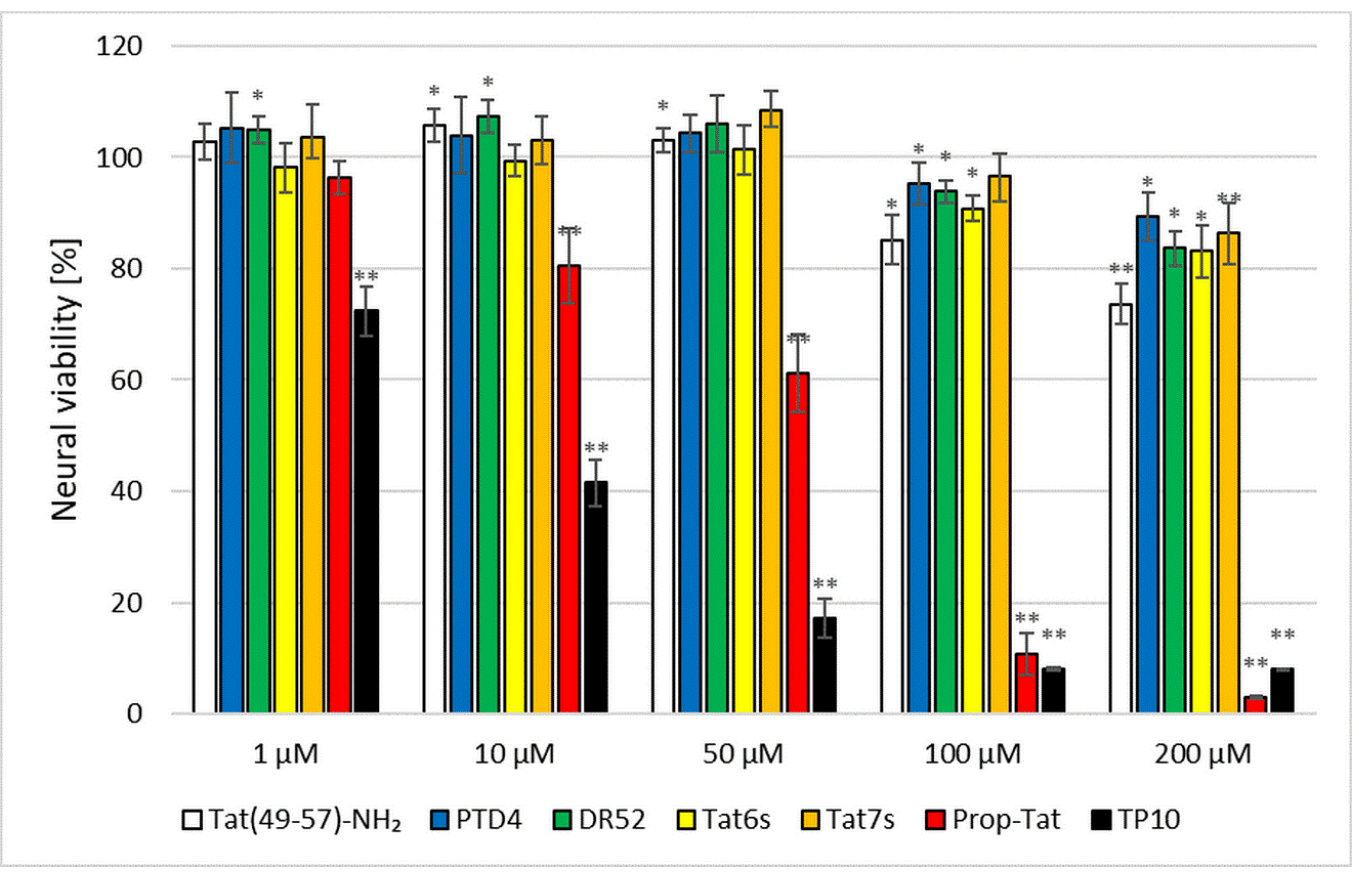

Figure 5. Peptide neurotoxicity in the cortical culture. Non-insulted cells were treated as $100 \%$ control. Data demonstrate relative measurements to control \pm SD. Two-way ANOVA statistics: $n=3$; ${ }^{*} p<0.05,{ }^{* *} p<0.001$.
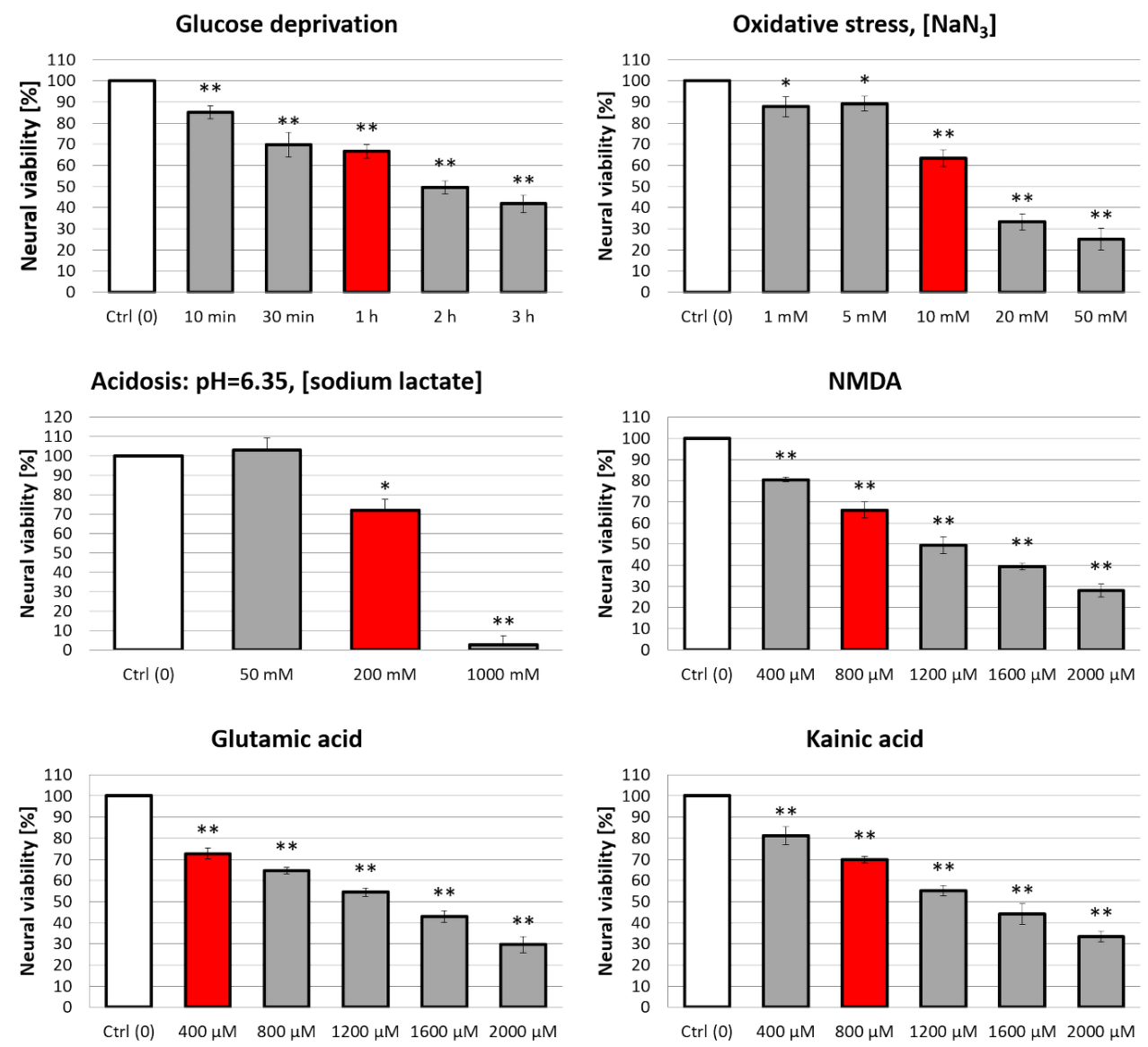

Figure 6. Optimization of an in vitro model of AIS. Red bars indicate conditions causing a 30-40\% decrease in neural viability. These conditions were then selected for assessments of the neuroprotective activity of tested peptides. Non-insulted cells were treated as $100 \%$ control. Two-way ANOVA statistics: $n=3{ }^{*} p<0.05,{ }^{* *} p<0.001$. Each statistical significance asterisk refers to a respective control (white bar) \pm SD. 
Neural cultures were exposed to each peptide for $20 \mathrm{~h}$, after which time their viability was assessed using a conventional spectrofluorimetric CellTiter-Blue ${ }^{\circledR}(\mathrm{CTB})$ assay (Figure 4) [63].The CTB assay was selected to replace a standard MTT agent. Although MTT was shown to perform excellent effectiveness in stable cell lines [64], several reports demonstrated its ill-disposed accuracy in the assessment of drug-dose response in cell lines [65,66] and neuron-astroglia cultures [67]. Figure 5 presents results of neurotoxicity. At low concentrations (up to $50 \mu \mathrm{M}$ ), the Tat peptides demonstrated no or low neurotoxicity. In this concentration range, PTD4 neurotoxicity was negligible, albeit significant neurotoxic effects of Tat peptides were visible at higher concentrations $(>100 \mu \mathrm{M})$, at which the most toxic impact was observed for Tat(49-57)- $\mathrm{NH}_{2}$. Within this concentration range, the Tat analogues displayed slightly lower toxicity than that of Tat(49-57)- $\mathrm{NH}_{2}$. In contrast, acute neurotoxicity was evident in the cases of Prop-Tat and the TP10 peptide. The neurotoxic impact of these agents was visible in a concentration of $1 \mu \mathrm{M}, \mathrm{TP} 10$ being the most pronounced. In high concentrations $(>100 \mu \mathrm{M})$, Prop-Tat and TP10 peptides reduced neural viability to $<10 \%$. Among all the peptides tested, TP10 displayed the highest toxicity in a wide concentration range. In summary, the Tat peptides studied showed no or negligible neurotoxicity in a concentration below $100 \mu \mathrm{M}$. The highest nontoxic peptide concentration of $50 \mu \mathrm{M}$ was used to assess their pro-viable effects. Because PTD4 displayed the lowest neurotoxicity among Tat analogues used in this study, this peptide was evaluated in terms of increasing neural viability in an in vitro model of AIS.

\subsection{PTD4 Is Pro-Viable in an In Vitro Model of Acute Ischemic Stroke}

We selected Tat(49-57)- $\mathrm{NH}_{2}$ and PTD4 peptides to validate the influence of Arg $52,55,57$, Lys $^{50,51} \rightarrow$ Ala substitutions, that resulted in the peptide net charge decrease (from +9 to +4 , respectively) in the neural survival induced by these peptides (Table 1). This influence was evaluated in an optimized multifactorial cellular model of AIS. The optimization of this model is shown in Figure 6. The conditions that caused a 30-40\% decrease in the neural viability within one hour of the exposure period (red bars) were selected for further assessment of pro-viable activities of the peptides.

In this model, rat primary neural culture was individually pre-treated with a series of AIS-related neurochemical injury factors (insults) such as glucose deprivation, oxidative stress (OS, induced by sodium azide), lactic acidosis, and excitotoxicity (induced separately by NMDA, glutamic acid or kainic acid). It is to be noted that, sodium azide, a typical inhibitor of complex IV in the respiratory chain, has been commonly used to induce OS in vitro and in vivo [68-71]. Likewise, acidosis was optimized using sodium lactate. Lactate is a metabolite of anaerobic respiration that occurs upon energetic deprivation, and has been widely used to mimic acidosis in excitotoxicity research [72-74]. The model was optimized based on classical studies. Excitotoxic factors: glutamic acid, kainic acid, and NMDA were applied as described elsewhere $[16,22,28,31,55,75]$. The results of this optimization are presented in Figure 6 . The intensity of these insult conditions was optimized in order to reduce the neural viability to the level of only $60-70 \%$ of the initial value (control conditions). These cells that were initially pre-exposed to normalized insult factors were subsequently exposed to Tat(49-57)- $\mathrm{NH}_{2}$ or PTD4 in the concentration of $50 \mu \mathrm{M}$, which was selected according to the neurotoxicity assessment (Figure 5).

The PTD4 peptide was chosen for this evaluation because of its best performance in neural viability assessment among all Tat tested analogues. The highest non-toxic concentration was selected, however, using a wider range of concentration $(1-10 \mu \mathrm{M})$ that would give a more conclusive insight into the peptide's activity $[76,77]$. The results of neural viability validation are presented in Figure 7. A post-insult 20-h exposure to each peptide revealed their significant survival-stimulating properties against almost all insults except sodium azide-induced oxidative stress. The yields of this ameliorating effect were similar for both peptides, amounting to about $10 \%$. The most pronounced peptide activity was observed as alleviation of energetic deprivation and excitotoxicity. The peptides did 
not prevent neural death caused by cellular respiration inhibition. In the case of acidosis, only PTD4 displayed pro-viable activity.

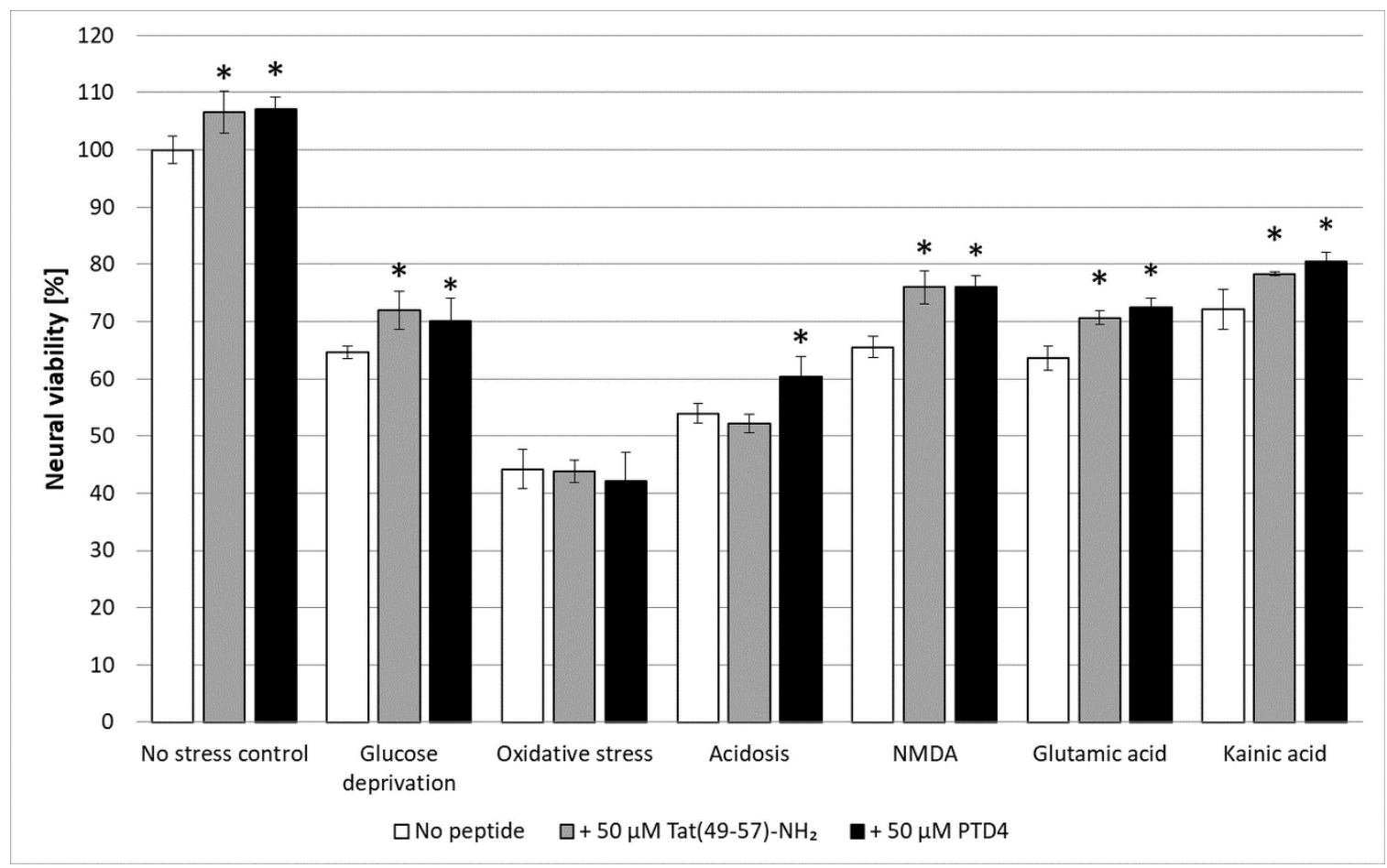

Figure 7. Pro-viable activity of Tat(49-57)- $\mathrm{NH}_{2}$ and PTD4 peptides in a multifactorial in vitro model of AIS. Non-insulted cells were treated as 100\% control. Two-way ANOVA statistics: $n=3 ;{ }^{*} p<0.05$. Each statistical significance asterisk refers to a respective no-peptide control (white bar) $\pm \mathrm{SD}$.

\section{Discussion}

According to WHO reports, strokes are the second leading cause of death and the third leading cause of disability worldwide. This vast group of cerebrovascular disorders is commonly divided into ischemic and hemorrhagic strokes. Whilst successful hemorrhage prevention usually depends on instant surgical bloodstream stemming, the physiological restoration of blood flow within impaired tissue in ischemic penumbra is possible by pharmacological treatment immediately after the insult [78-80]. Recently developed, brain-targeted drug-delivery systems employ CPPs, peptides with an intrinsic ability to effectively traverse the cell membrane and an inherent capacity for neuroprotection [81]. Despite the identification of over a thousand CPPs, recent clinical trials have mostly concerned the neuro-application of Tat peptides, i.e., fragments or analogues of the ARM of HIV-1 Tat protein, that display beneficial neuro-oriented propensities, such as structural flexibility, modification easiness, receptor binding selectivity, and crossing the blood-brain barrier (BBB) $[13,82]$. All of these taken together make CPPs the perfect candidates for the starting point for the future pharmacological therapy of AIS.

Clinical application of Tat peptides as a cure for neurological diseases is troublesome due to ambivalent outcomes of their activity. Despite the undeniably deleterious neuropathology of HIV-1 Tat protein, high-throughput in in vitro and in vivo studies demonstrated dose-dependent anti-stroke neuroprotection of HIV-1 Tat-derived Tat peptides and their RRP analogues $[22,83,84]$. The aim of our study was to verify whether conformational properties increased pro-viable activity of arginine-rich Tat(49-57)- $\mathrm{NH}_{2}$ and its less basic analogue PTD4. First, we analyzed the neurotoxicity of selected Tat analogues in the $1-200 \mu \mathrm{M}$ concentration range. In general, the native sequence of Tat(49-57)- $\mathrm{NH}_{2}$ and its analogues did not show significant differences in neurotoxicity up to a concentration of $50 \mu \mathrm{M}$. Above this value, a progressive increase in neurotoxicity of the peptides was 
visible. At higher concentrations, the Tat analogues were less neurotoxic than the native sequence, thus indicating that PTMs may modulate and inhibit the neurotoxic effect. For Prop-Tat and TP10, acute neurotoxicity was observed even at low peptide concentration, which may be associated with their high ability to translocate through the cell membrane or bind to a specific membrane receptor. These results show that not all CPPs are useful as potential neuroprotective agents and suggest that, in some cases, the alkynyl components of the click-reaction may be neurotoxic. Future elucidation using the structure-activity relationship (SAR) method will shed more light on critical molecular properties of PTM Tat analogues required for their neuroprotection.

Potential neuroprotective activity of PTD4, in the highest non-toxic concentration $(50 \mu \mathrm{M})$, was analyzed in an in vitro model of AIS. Previous studies showed the use of sodium azide and sodium lactate to induce oxidative stress and acidosis, respectively [68-74]. As well, a series of studies was executed to optimize oxygen-glucose deprivation and excitotoxicity $[16,22,28,31,55,75]$. PTD4 exhibited lower toxicity and mild but higher neuroprotection in comparison to the native sequence of Tat(49-57)- $\mathrm{NH}_{2}$. In particular, both peptides were significantly neurotoxic at concentrations above $100 \mu \mathrm{M}$, but this effect for Tat(49-57)$\mathrm{NH}_{2}$ was markedly higher. The possible reasons for the neurotoxicity of both peptides may be correlated with already-established Tat-induced elevation of cytosolic calcium levels [85], excitotoxicity [86,87], mitochondrial dysfunction and oxidative stress [88], and blocked autophagy [89], as well as alterations of signal trafficking [24,89]. From this perspective, the PTD4 peptide emerges as a better-performing anti-AIS drug candidate than Tat(49-57)- $\mathrm{NH}_{2}$.

The maximal active concentration predisposing PTD4 and Tat(49-57)- $\mathrm{NH}_{2}$ peptides for neuronal targeting was as high as $50 \mu \mathrm{M}$. Previous studies, however, demonstrated an augmenting effect of lower doses $(0.1-5 \mu \mathrm{M})$, yet added prior to the insult and for a shorter time (from $15 \mathrm{~min}$ to $2 \mathrm{~h}$ ) $[22,28,31,83,90]$. This discrepancy may result from different conditions and doses of insults applied in these studies. In our study, we applied an increased concentration of the insult to provide mild, but sufficient neural mortality ( $40 \%)$. Therefore, the peptide concentration and exposition duration to the peptides were increased accordingly $[75,91,92]$. In our model, peptide treatment modestly inhibited neural death caused by all insults, excluding sodium azide-induced oxidative stress. The effects of PTD4 and Tat(49-57)- $\mathrm{NH}_{2}$ differed in the case of acidosis as the former exhibits ameliorating activity. Despite well-documented data about the high vulnerability of neurons to acidic $\mathrm{pH}$ and the destructive impact of lactic acid [74,93-95], it is not clear whether CPPs may ameliorate the effects of acidosis. To add, CPPs display pronounced protection against mitochondrial dysfunction [96-98]. Our results shed new light on this activity of several RRPs in lactic acidosis.

Comparing the native Tat(49-57)- $\mathrm{NH}_{2}$ and PTD4, the latter appeared as a betterperforming neuroprotectant in the AIS model. Mechanistically, this may indicate a possible correlation between neuroprotection and the structural and acid-base peptide properties. Seemingly, pro-viable activity of the peptides is more likely enhanced by facilitated intracellular peptide uptake than the net positive charge of a peptide. This observation is consistent with previous reports, which showed that the efficiency of peptide translocation across the cell membrane is almost thirty times higher in the case of PTD4 compared to Tat(49-57)- $\mathrm{NH}_{2}[99,100]$. Specific properties of Tat(49-57)- $\mathrm{NH}_{2}$ and PTD4, such as relatively similar basicity but different net charges (Table 1), may imply diverse mechanisms of transmembrane internalization of these peptides. The results presented in our study showed that even though the unstructured folding in both peptides was observed in physiological conditions, a helical conformation is adopted only by the PTD4 peptide.

Stroke-related Tat-induced neuroprotection has been demonstrated and exploited in pre-clinical studies and a recently concluded Phase III clinical trial on nerinetide, an eicosapeptide neuroprotectant that interferes with PSD-95 in human ischemia-reperfusion and occurs with rapid endovascular thrombectomy in AIS patients (ClinicalTrials.gov Identifier: NCT02930018, [101]). Yet, unraveling the molecular mechanism underlying its activity re- 
mains a challenging task. As is known, Tat(48-57) neuroprotection in stroke models strongly depends on the route of administration of the peptide, e.g., in contrast to intraperitoneal delivery, the intracerebroventricular injection of this peptide enabled neuroprotection against cerebral ischemia [83,102]. Besides, fused RRPs were used for symptomatic therapies of global cerebral ischemia [103] and focal ischemic stroke (PTD fused with BCL-XL [104], GDNF [105], and HSP70 [106]). In this context, our results show that the direct delivery of Tat(49-57)- $\mathrm{NH}_{2}$ on pre-insulted neural cells provides neuroprotection against several neurochemical impacts of stroke. We also showed similar neuroprotective properties of PTD4, which was already demonstrated to reverse stroke impacts when administrated intravenously $[13,14]$. This intrinsic in vitro neuroprotection of PTD4 against stroke is in agreement with data already obtained for other RRPs [104,107-109]. Yet, in contrast to these studies, which correlate the RRP neuroprotection with the electrochemical properties and arginine content, the CD spectra presented in our study, indicate a tendency of PTD4 to adopt a helical conformation in a membrane-mimicking environment. This structural feature of PTD4, in addition to the lower basicity than that of Tat(49-57)- $\mathrm{NH}_{2}$, suggests that the traversing capability of PTD4 may originate from the helicity of this peptide rather than from its net charge.

As a BBB shuttle peptide, PTD4 is expected to interact with the cell membrane to enter brain parenchyma $[13,14]$, either in a receptor-independent fashion [110] or via endocytosis or adsorptive-mediated transcytosis [111]. On the contrary to the endocytosis of regular peptides, during which these peptides are encapsulated in the endocytic vesicle, PTD4, as well as other RRPs, enter the cell interior together with an outer membrane receptor or transmembrane channel, which removes them from the outer cell surface $[20,112,113]$. As known, RRP reduce an excitotoxic calcium influx to the cell interior by their interaction with glutamate agonist receptors [22,112,114]. This interaction induces endocytic internalization of calcium ion channels and transporters, such as an NR2B subunit of NMDA receptor (NMDAR), i.e., a pivotal modulator of excitotoxic neuronal calcium influx and the damaging of signaling in neurons [31]. However, the experimental data on this topic is still ambivalent [115] as Tat peptides were demonstrated either to inhibit NMDAR and lower the toxic intracellular calcium ions level [5,55], or else to trigger glutamate- or NMDA-induced calcium influx $[115,116]$. From this perspective, PTD4 and Tat(49-57)$\mathrm{NH}_{2}$, assessed in our in vitro model of AIS, displayed significant neuroprotection against excitotoxicity. Similar ameliorating effects were obtained for hybrid Tat peptides, which were shown to inhibit the activity of the kainite receptor and NMDA-NR2B subunit [108], as well as of NMDAR-PSD-95 complex formation in the intracellular part of NMDAR [31], and which may induce blocking nitric oxide synthase (NOS) activation and nitric oxide (NO) production in mitochondria [31].

Additionally, because mitochondria-penetrating RRPs are capable of indirect prevention of ATP synthesis, maintenance of cytochrome $c$ integrity and attenuation of calcium influx-induced neurotoxicity [31], it may be speculated that Tat(49-57)- $\mathrm{NH}_{2}$ and PTD4 exhibit an indirect protecting effect against pathological processes occurring in mitochondria, such as glucose deprivation, as indicated by outcomes of our study. The already described mechanisms of Tat and other RRPs-induced neuroprotection mention the stabilization of mitochondrial membrane as well as the inhibition of furin, i.e., a calcium-dependent protein convertase [117]. These pro-viable activities forestall the maturation of proteins involved in stroke-induced death signaling pathways in neurons. Besides, the participation of RRPs in the downregulation of voltage-gated CaV2.2, CaV3.3, and NCX3 and TRPV1 ion channels was reported as well [31].

In summary, our results may be the first inceptive for the discovery of the mechanistic details of Tat(49-57)- $\mathrm{NH}_{2}$ and PTD4 peptide. Aside from their well-established activity as drug delivery systems in anti-AIS therapy, these peptides may display inherent neuroprotection against AIS. This pro-viable activity in neural cells may be correlated with capability of these peptides to adopt a helical conformation rather than with the arginine content. 


\section{Materials and Methods}

\subsection{Peptides Synthesis and Purification}

CPPs were synthesized with the use of an automated peptide synthesizer as C-terminal amides on TentaGel S RAM amide resin $\left(0.25 \mathrm{mmol} \mathrm{NH}_{2} / \mathrm{g}\right.$ capacity) using Fmoc chemistry and TBTU as a coupling reagent. Propynoic acid was coupled manually to the $\mathrm{N}$-terminal end of the immobilized Tat peptide in the last step of the synthesis using a 10-fold molar excess of propiolic anhydride 30. The peptides were cleaved from the peptidyl-resin by treatment with a mixture of TFA/phenol/water/triisopropylsilane (TIPS) $(88 / 5 / 5 / 2)$ at room temperature (RT) for $3 \mathrm{~h}$ under argon bubbles. The crude peptides were precipitated and washed with ice-cold diethyl ether. After lyophilization, the peptides were purified by preparative RP HPLC (Dr Maisch C-18 column with the dimensions of $250 \mathrm{~mm} \times 40 \mathrm{~mm}$, particles of $10 \mu \mathrm{m})$. Several gradient methods of acetonitrile (ACN) with $0.08 \%$ TFA with a flow rate of $25 \mathrm{~mL} / \mathrm{min}$ were used throughout the purification. Fractions of the highest purity ( $>95 \%$ ) were analyzed by analytical RP HPLC using a Phenomenex Kinetex XB-C18 column with the dimensions of $150 \mathrm{~mm} \times 4.6 \mathrm{~mm}$, particles of $5 \mu \mathrm{m}$ with several gradient methods of ACN with $0.08 \%$ TFA and a flow rate of $1 \mathrm{~mL} / \mathrm{min}$. After purification and lyophilization, the peptides were dissolved in $0.01 \mathrm{M} \mathrm{AcOH}$ for trifluoroacetate to acetate ion exchange and relyophilized. Afterwards, the peptide homogeneity was characterized by analytical RP HPLC, capillary electrophoresis (CE), and ESI-MS using the QTOF 5600+ (Sciex, Framingham, MA, USA) mass spectrometer. The physicochemical properties of the peptides are summarized in Table 1.

\subsection{Circular Dichroism Spectroscopy}

Circular dichroism (CD) spectra of peptides were recorded on a Jasco J-815 spectropolarimeter (Jasco Int. Co., Ltd., Tokyo, Japan). The CD spectra were acquired for peptides in a concentration of $0.15 \mathrm{mg} / \mathrm{mL}$ in $10 \mathrm{mM}$ PBS buffer (pH 7.0) or 30\% (v/v) 2,2,2trifluoroethanol (TFE) in $0.1 \mathrm{~cm}$ path length cuvettes and were measured in $185-250 \mathrm{~nm}$ spectral range at $25^{\circ} \mathrm{C}$. Ellipticity was measured in mdeg units. The spectra were averaged after three scans.

\subsection{Molecular Dynamics Calculations}

Peptide structures were constructed using standard modules from the AMBER 16 package [118]. Raw models were initially energy-minimized and submitted to the $100 \mathrm{~ns}$ unconstrained molecular dynamics (MD) simulation in the ff15ipq force field available in the AMBER suite of programs [119]. The MD simulations were conducted using two different solvents for each MD run: water and 30\% $(v / v)$ TFE aqueous solution. The standard pairwise generalized Born solvation model was used throughout all MD simulations. For the TFE solution, a dielectric constant of 43.06 was set [120]. Resulting trajectories were analyzed using the CPPTRAJ module of AMBER and hierarchical agglomerative (bottom-up) algorithm for clustering analysis [121]. Ten clusters were acquired for each trajectory. Representative structures of the two most populated clusters were obtained for each condition. All figures were evaluated using the MOLMOL 2K.2 software, date: 20 January 2003; [122].

\subsection{Primary Neural Cortical Cultures}

All animal experiments were conducted in accord with the permission of the Local Bioethics Committee. Primary cortical neurons were isolated from Wistar rat embryos at embryonic day 18.5 (E18.5). Pregnant females were euthanized in a $\mathrm{CO}_{2}$ chamber, and the embryos were immediately removed in order to microdissect the brains. The cortices were excised, transferred to Hank's Balanced Salt Solution (HBSS, Gibco, Waltham, MA, USA), supplemented with a $1 \%$ penicillin/streptomycin mixture (Gibco, Waltham, MA, USA) and washed. Afterwards, the tissue was trypsinized (2.5\% trypsin, Gibco, Waltham, MA, USA) for $10 \mathrm{~min}$ at $37^{\circ} \mathrm{C}$, and homogenized gently by re-suspension with a sterile tip of a pipette. The cell suspension was centrifuged in $300 \mathrm{rcf}$ for $4 \mathrm{~min}$ and re-suspended in 
Neurobasal-A medium (Gibco, Waltham, MA, USA) supplemented to final concentration with $1 \mathrm{mM}$ sodium pyruvate, $12.5 \mathrm{mM}$ glucose $2 \%$ B27 (Gibco, Waltham, MA, USA), $200 \mathrm{mM}$ L-glutamine, $10 \mathrm{mM}$ glutamic acid, a 1\% penicillin/streptomycin mixture, and seeded in a 24-well plate poly-D-lysine (PDL)-coated (BioCoat, Corning, Tewksburry, MA, USA) in the number of 200,000 cells per well. The neural cultures were incubated in a $\mathrm{CO}_{2}$ chamber $\left(5 \%, 95 \%\right.$ air balance, $98 \%$ humidity, $\left.37^{\circ} \mathrm{C}\right)$ for 14 days and were used on culture day in vitro (DIV) $14-15$.

\subsection{Optimization of an In Vitro Model of Acute Ischemic Stroke}

\subsubsection{Optimization of Glucose Deprivation}

For glucose deprivation, after removing culture medium from 24-well plates, neural cells were rapidly washed with $300 \mu \mathrm{L}$ PBS (pH 7.4) and then incubated with $500 \mu \mathrm{L}$ of glucose- and sodium pyruvate-free Neurobasal-A medium (described above) for 10 and $30 \mathrm{~min}$, and 1,2, and $3 \mathrm{~h}$ in a standard $\mathrm{CO}_{2}$ chamber. Each plate contained control cells that were incubated in a standard Neurobasal medium. Upon removal of the plates from an incubator, the media from all wells were aspirated and replaced with $500 \mu \mathrm{L}$ of fresh, standard culture medium. The cells were cultivated in such conditions in a standard $5 \%$ $\mathrm{CO}_{2}$ chamber $\left(37^{\circ} \mathrm{C}\right)$ for $20 \mathrm{~h}$.

\subsubsection{Optimization of the Sodium Azide-Induced Inhibition of Cellular Respiration}

Oxidative stress was modeled by exposing neural cells to sodium azide to inhibit cellular respiration. After removing the culture medium from 24-well plates, the cells were rapidly washed with $300 \mu \mathrm{L}$ of PBS and subsequently incubated with medium containing 1 , $5,10,20$, or $50 \mathrm{mM}$ sodium azide for $1 \mathrm{~h}$ in a standard $5 \% \mathrm{CO}_{2}$ chamber $\left(37^{\circ} \mathrm{C}\right)$. Afterwards, the medium was exchanged for $500 \mu \mathrm{L}$ of standard Neurobasal medium, and the cells were incubated for $20 \mathrm{~h}$ in a $5 \% \mathrm{CO}_{2}$ chamber $\left(37^{\circ} \mathrm{C}\right)$.

\subsubsection{Optimization of Acidosis}

Culture medium for acidosis was optimized in terms of $\mathrm{pH}$ and concentration of sodium lactate. For optimization, culture media were aspirated from 24-wells and the cells were washed rapidly with $300 \mu \mathrm{L}$ PBS (pH 7.4) and incubated with $500 \mu \mathrm{L}$ of a Neurobasal of $\mathrm{pH} 7.4$ (control), 6.5, 6.35, 5.55, 5.2, and 4.6. The $\mathrm{pH}$ was adjusted with $0.1 \mathrm{M} \mathrm{HCl}$. The sodium lactate concentration was optimized similarly by incubating the cells in a medium containing 50, 200, and $1000 \mathrm{mM}$ sodium lactate for $1 \mathrm{~h}$. Finally, the synergistic effect of both factors was measured. In all cases, after $1 \mathrm{~h}$, the stress-containing media were switched to fresh Neurobasal media and cells were incubated in a standard $\mathrm{CO}_{2}$ chamber $\left(37^{\circ} \mathrm{C}\right)$ for $20 \mathrm{~h}$.

\subsubsection{Optimization of Excitotoxicity Models}

Excitotoxicity was evaluated in three individual models, including glutamic acid, $\mathrm{N}$-methyl-D-aspartate (NMDA) and kainic acid. All excitotoxic inducers were freshly prepared prior to the experiment and evaluated in concentrations of 400, 800, 1200, 1600, and $2000 \mu \mathrm{M}$. Application of the inducers followed the removal of the culture media from the 24-well plates and washing the cells with $300 \mu \mathrm{L} \mathrm{PBS} \mathrm{(pH} \mathrm{7.4).} \mathrm{The} \mathrm{cells} \mathrm{were}$ subsequently incubated for $1 \mathrm{~h}$ with a stressor in a concentration of 400, 800, 1200, 1600, and $2000 \mu \mathrm{M}$. Then, media were exchanged for $500 \mu \mathrm{L}$ of a standard Neurobasal medium, and the cells were incubated for $20 \mathrm{~h}$.

\subsection{Treatment of Neural Cultures with Peptides}

The influence of all peptides on neural viability was assessed by exposing the cells to different peptide concentrations $(1,10,50,100,200 \mu \mathrm{M})$ for $20 \mathrm{~h}$ at $37^{\circ} \mathrm{C}$ in a $5 \% \mathrm{CO}_{2}$ chamber. The assessments were performed in 24-well PDL-coated plates (BioCoat, Corning, Tewksbury, MA, USA) with a working volume of $500 \mu \mathrm{L} /$ well. The respective peptide 
solutions were prepared in culture medium so that in all wells only $50 \mu \mathrm{L}$ of the medium was exchanged, including control (untreated) samples.

\subsection{Pro-Viable Effect of the Peptides in an In Vitro Model of Acute Ischemic Stroke}

The pro-viable properties of the tested peptides were studied in a neural model of brain injury, including glucose deprivation (Neurobasal-A, Gibco, Waltham, MA, USA), acidosis ( $\mathrm{pH}$ 6.35, $200 \mathrm{mM}$ sodium lactate), inhibition of cellular respiration (10 mM $\mathrm{NaN}_{3}$ ), and excitotoxicity (400 $\mu \mathrm{M}$ glutamic acid, $800 \mu \mathrm{M}$ NMDA, $800 \mu \mathrm{M}$ kainic acid; each analyzed independently). The activities of individual peptides were analyzed on two 24-well plates, each containing three 6-well rows for three insult conditions: one plate included excitotoxicity, the other included glucose deprivation, acidosis, and oxidative stress. The remaining row on each plate provided wells for control samples. On each plate, one half of each row was predestined to the treatment with the respective insult factor and then with the fresh medium. The other half of each row was treated with the same injury factor followed by incubation with the respective peptide. All insult factor media were freshly prepared before use, and cells were exposed to a $1 \mathrm{~h}$ incubation with an insult fact. Afterwards, the cells were carefully washed with $300 \mu \mathrm{L}$ of PBS. The twelve wells that included the control and insult-treated samples were incubated with fresh culture medium, whereas the remaining wells were treated with a medium containing the respective peptides. Prior to use, the peptides were dissolved in Neurobasal medium in final concentrations of $50 \mu \mathrm{M}$. A $20 \mathrm{~h}$ incubation in standard conditions was followed with the neural viability assessment, as described -in the paragraph 4.8 .

\subsection{Neural Viability Assessments}

Neural viability was assessed in CellTiter-Blue ${ }^{\circledR}$ (CTB) assay (Promega, cat \#G8080, Madison, WI, USA) after $20 \mathrm{~h}$ long incubation of cells in standard Neurobasal medium after stressful conditions. The test was performed in 24-well PDL-coated plates (BioCoat, Corning, Tewksbury, MA, USA) and according to the manufacturer's guideline, which included adding the solution to the neural culture well, followed by incubation for $1-4 \mathrm{~h}$ at $37^{\circ} \mathrm{C}$ $\left(5 \% \mathrm{CO}_{2}\right)$. The fluorescence intensity of the CTB reagent was measured spectrofluorimetrically $\left(560_{\mathrm{ex}} / 590_{\mathrm{em}}\right)$ and was proportional to the number of viable cells. The results were calculated as a percentage taking the respective control (non-insulted) measurement as $100 \%$ viability.

\subsection{Statistical Analysis}

Each cell viability experiment was performed in at least three biologically independent experiments, in each of which neural cultures were obtained from one female rat. Each female originated from different breeding parents. In one experiment, the viability assessments for each condition were conducted in three plates, with three-four replicate wells per plate. For every plate, relative viability for one condition were averaged, and then used to calculate averaged results for all plates in an experiment. The final values were calculated from averaged results of independent experiments and shown as a mean \pm standard deviation (SD), $n=3$. The data were analyzed by a two-way ANOVA test with $p$-value $<0.05$ values considered statistically significant.

\section{Conclusions}

Tat peptides containing the HIV-1 Tat arginine-rich motif demonstrated no neurotoxicity up to concentration of $50 \mu \mathrm{M}$. This outcome allows for the use of these cell-penetrating peptides as pro-viable and neuroprotective agents. Pro-viable properties of Tat(49-57)- $\mathrm{NH}_{2}$ and its analogue, PTD4, were verified in a multifactorial in vitro model of acute ischemic stroke. Significant effects of PTD4 against severe metabolic outcomes of AIS may suggest important mechanistic implications. Based on our results, we propose a conjectured mechanism of PTD4-mediated neuroprotection (Figure 8). Being less basic, PTD4 provided comparable yet broader neuroprotection as the native Tat(49-57)- $\mathrm{NH}_{2}$ peptide. This fact 
argues against a well-established mechanism relying on the crucial involvement of arginine guanidinium groups of RRPs' interactions with the neuronal membrane. From this perspective, PTD4 seems to be the most suitable arginine-rich peptide in terms of neuroprotection among the tested peptides. In conclusion, PTD4 displayed mild pro-viable activity in ischemia-stricken neural cells. This propensity may predispose the PTD4 peptide to act as a leading targeting molecule attributed with inherent neuropharmacological activity against acute ischemic stroke.

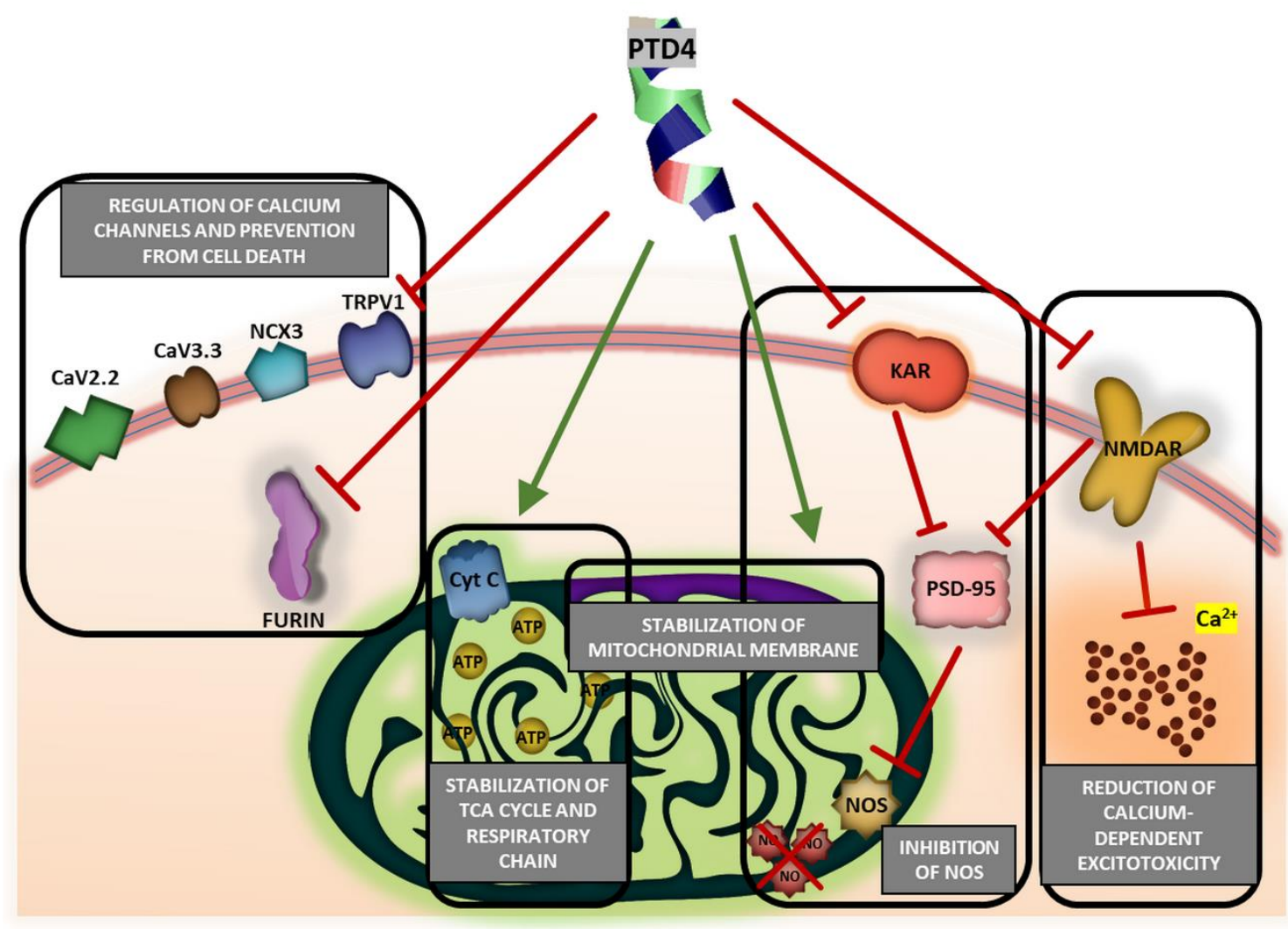

Figure 8. Conjectured mechanisms of PTD4-mediated neuroprotection based on the results of the study. PTD4$\mathrm{Y}^{47}$ ARAAARQARA ${ }^{57}$-amide; CaV2.2-N-type voltage-gated calcium channel; CaV3.3-T-type voltage-gated calcium channel; NCX3-sodium-calcium exchanger 3; TRPV1-transient receptor potential cation channel subfamily V member 1; Cyt Ccytochrome C; ATP-adenosine triphosphate; NOS-nitric oxide synthase; NO-nitric oxide; PSD-95-post-synaptic density protein 95; KAR-kainic acid receptor; NMDAR-N-methyl-D-aspartic acid receptor; TCA-tricarboxylic acid cycle.

Supplementary Materials: The following are available online at https: / www.mdpi.com/article/ $10.3390 /$ ijms22116086/s1.

Author Contributions: Conceptualization, J.M., K.K., M.B.W., A.P., Ł.J., P.M.S., M.P., P.S., S.R.-M., A.C. and P.M.; methodology, J.M., I.P., K.K., M.J.Ś., J.R., P.R. (Piotr Rekowski), P.R. (Piotr Rogujski), R.P., M.B.W., S.R.-M., A.C. and P.M.; software, M.J.Ś.; validation, J.M. and P.M.; formal analysis, J.M. and P.M.; investigation, J.M. and P.M.; resources, J.M., I.P., K.K., M.J.Ś., J.R., P.R. (Piotr Rekowski), P.R. (Piotr Rogujski), R.P., M.B.W., S.R.-M., A.C. and P.M; data curation, J.M., I.P., K.K., M.J.Ś., J.R., P.R. (Piotr Rekowski), P.R. (Piotr Rogujski), R.P. and P.M.; writing-original draft preparation, J.M. and P.M.; writing-review and editing, J.M., M.B.W., S.R.-M., A.C. and P.M.; visualization, J.M., I.P., K.K., M.J.Ś., P.R. (Piotr Rogujski); supervision, A.C. and P.M.; project administration, S.R.-M., A.C. and P.M.; funding acquisition, A.P., Ł.J., P.M.S., P.S., M.P., S.R.-M., A.C. and P.M. All authors have read and agreed to the published version of the manuscript.

Funding: This research was funded by the National Centre for Research and Development-Poland (grant no. STRATEGMED1/235077/9/NCBR/2014). K.K. and M.B.W. were additionally supported by the Polish National Science Centre (grant no. 2015/19/B/NZ4/03571NCN). 
Institutional Review Board Statement: The study was conducted according to the guidelines of the Declaration of Helsinki, approved by the First Local Ethics Committee in Warsaw (permit no. $491 / 2013,10.10 .2013$ ) and strictly followed the rules of the Polish Animal Protection Act. Animal experimentation was carried out in accordance with EU directive 2010/63/EU (22 September 2010).

Informed Consent Statement: Not applicable.

Data Availability Statement: The datasets used and/or analyzed during the current study are available from the corresponding author on reasonable request.

Conflicts of Interest: The authors declare no conflict of interest. The funders had no role in the design of the study, in the collection, analyses, or interpretation of data, in the writing of the manuscript, or in the decision to publish the results.

$\begin{array}{ll}\text { Abbreviations } & \\ \text { AIS } & \text { Acute ischemic stroke } \\ \text { ARM } & \text { Arginine rich motif } \\ \text { BBB } & \text { Blood-brain barrier } \\ \text { CD } & \text { Circular dichroism } \\ \text { CPP } & \text { Cell penetrating peptide } \\ \text { CTB } & \text { CellTiter-Blue } \\ \text { FDA } & \text { Food and drug administration } \\ \text { HAND } & \text { HIV-associated neurological disorder } \\ \text { HIV } & \text { Human immunodeficiency virus } \\ \text { MD } & \text { Molecular dynamics } \\ \text { NMDA } & \text { N-methyl D-aspartate } \\ \text { NMDAR } & \text { NMDA receptor } \\ \text { NMDAR-PSD } & \text { NMDAR postsynaptic density protein } \\ \text { NO } & \text { Nitric oxide } \\ \text { NOS } & \text { Nitric oxide synthase } \\ \text { OS } & \text { Oxidative stress } \\ \text { PTD } & \text { Protein transduction domain } \\ \text { PTM } & \text { Post-translational modification } \\ \text { RRP } & \text { Arginine rich peptide } \\ \text { rtPA } & \text { Recombinant tissue plasminogen activator } \\ \text { TAT } & \text { Transactivator of transcription } \\ \text { TFE } & \text { Trifluoroethanol }\end{array}$

\section{References}

1. Feigin, V.L.; Forouzanfar, M.H.; Krishnamurthi, R.; Mensah, G.A.; Connor, M.; Bennett, D.A.; Moran, A.E.; Sacco, R.L.; Anderson, L.; Truelsen, T.; et al. Global and regional burden of stroke during 1990-2010: Findings from the Global Burden of Disease Study 2010. Lancet 2014, 383, 245-254. [CrossRef]

2. Mozaffarian, D.; Benjamin, E.J.; Go, A.S.; Arnett, D.K.; Blaha, M.J.; Cushman, M.; Das, S.R.; de Ferranti, S.; Despres, J.P.; Fullerton, H.J.; et al. Heart Disease and Stroke Statistics-2016 Update: A Report From the American Heart Association. Circulation 2016, 133, e38-e360. [CrossRef] [PubMed]

3. Luengo-Fernandez, R.; Violato, M.; Candio, P.; Leal, J. Economic burden of stroke across Europe: A population-based cost analysis. Eur. Stroke J. 2020, 5, 17-25. [CrossRef] [PubMed]

4. Wang, Q.; Yu, S.; Simonyi, A.; Sun, G.Y.; Sun, A.Y. Kainic acid-mediated excitotoxicity as a model for neurodegeneration. Mol. Neurobiol. 2005, 31, 3-16. [CrossRef]

5. Meloni, B.P.; Brookes, L.M.; Clark, V.W.; Cross, J.L.; Edwards, A.B.; Anderton, R.S.; Hopkins, R.M.; Hoffmann, K.; Knuckey, N.W. Poly-arginine and arginine-rich peptides are neuroprotective in stroke models. J. Cereb. Blood Flow Metab. Off. J. Int. Soc. Cereb. Blood Flow Metab. 2015, 35, 993-1004. [CrossRef]

6. National Institute of Neurological Disorders and Stroke rt-PA Stroke Study Group. Tissue plasminogen activator for acute ischemic stroke. N. Engl. J. Med. 1995, 333, 1581-1587. [CrossRef]

7. Ezzet, K.A. Reversal of acute ischemic stroke after THA using tissue plasminogen activator. Orthopedics 2013, 36, e676-e678. [CrossRef] [PubMed]

8. Kardani, K.; Milani, A.; H. Shabani, S.; Bolhassani, A. Cell penetrating peptides: The potent multi-cargo intracellular carriers. Expert Opin. Drug Deliv. 2019, 16, 1227-1258. [CrossRef] 
9. Rusiecka, I.; Ruczynski, J.; Kozlowska, A.; Backtrog, E.; Mucha, P.; Kocic, I.; Rekowski, P. TP10-Dopamine Conjugate as a Potential Therapeutic Agent in the Treatment of Parkinson's Disease. Bioconjug. Chem. 2019, 30, 760-774. [CrossRef]

10. Mishra, A.; Lai, G.H.; Schmidt, N.W.; Sun, V.Z.; Rodriguez, A.R.; Tong, R.; Tang, L.; Cheng, J.; Deming, T.J.; Kamei, D.T.; et al. Translocation of HIV TAT peptide and analogues induced by multiplexed membrane and cytoskeletal interactions. Proc. Natl. Acad. Sci. USA 2011, 108, 16883-16888. [CrossRef]

11. Schmidt, N.; Mishra, A.; Lai, G.H.; Wong, G.C. Arginine-rich cell-penetrating peptides. FEBS Lett. 2010, 584, 1806-1813. [CrossRef]

12. Fineberg, K.; Fineberg, T.; Graessmann, A.; Luedtke, N.W.; Tor, Y.; Lixin, R.; Jans, D.A.; Loyter, A. Inhibition of nuclear import mediated by the Rev-arginine rich motif by RNA molecules. Biochemistry 2003, 42, 2625-2633. [CrossRef] [PubMed]

13. Oller-Salvia, B.; Sanchez-Navarro, M.; Giralt, E.; Teixido, M. Blood-brain barrier shuttle peptides: An emerging paradigm for brain delivery. Chem. Soc. Rev. 2016, 45, 4690-4707. [CrossRef] [PubMed]

14. Sarantseva, S.V.; Bol'shakova, O.I.; Timoshenko, S.I.; Kolobov, A.A.; Vitek, M.P.; Shvartsman, A.L. Protein transduction domain peptide mediates delivery to the brain via the blood-brain barrier in Drosophila. Biomeditsinskaia Khimiia 2009, 55, 41-49. [CrossRef]

15. Kamori, D.; Ueno, T. HIV-1 Tat and Viral Latency: What We Can Learn from Naturally Occurring Sequence Variations. Front. Microbiol. 2017, 8, 80. [CrossRef] [PubMed]

16. Meloni, B.P.; Milani, D.; Edwards, A.B.; Anderton, R.S.; O'Hare Doig, R.L.; Fitzgerald, M.; Palmer, T.N.; Knuckey, N.W. Neuroprotective peptides fused to arginine-rich cell penetrating peptides: Neuroprotective mechanism likely mediated by peptide endocytic properties. Pharmacol. Ther. 2015, 153, 36-54. [CrossRef]

17. Ramirez-Alvarado, M.; Blanco, F.J.; Niemann, H.; Serrano, L. Role of beta-turn residues in beta-hairpin formation and stability in designed peptides. J. Mol. Biol. 1997, 273, 898-912. [CrossRef]

18. Reiersen, H.; Rees, A.R. Trifluoroethanol may form a solvent matrix for assisted hydrophobic interactions between peptide side chains. Protein Eng. 2000, 13, 739-743. [CrossRef]

19. Vives, E. Cellular uptake [correction of utake] of the Tat peptide: An endocytosis mechanism following ionic interactions. J. Mol. Recognit. JMR 2003, 16, 265-271. [CrossRef]

20. Ho, A.; Schwarze, S.R.; Mermelstein, S.J.; Waksman, G.; Dowdy, S.F. Synthetic protein transduction domains: Enhanced transduction potential in vitro and in vivo. Cancer Res. 2001, 61, 474-477.

21. Zou, L.L.; Ma, J.L.; Wang, T.; Yang, T.B.; Liu, C.B. Cell-penetrating Peptide-mediated therapeutic molecule delivery into the central nervous system. Curr. Neuropharmacol. 2013, 11, 197-208. [CrossRef]

22. Meloni, B.P.; Craig, A.J.; Milech, N.; Hopkins, R.M.; Watt, P.M.; Knuckey, N.W. The neuroprotective efficacy of cell-penetrating peptides TAT, penetratin, Arg-9, and Pep-1 in glutamic acid, kainic acid, and in vitro ischemia injury models using primary cortical neuronal cultures. Cell. Mol. Neurobiol. 2014, 34, 173-181. [CrossRef] [PubMed]

23. Cardozo, A.K.; Buchillier, V.; Mathieu, M.; Chen, J.; Ortis, F.; Ladriere, L.; Allaman-Pillet, N.; Poirot, O.; Kellenberger, S.; Beckmann, J.S.; et al. Cell-permeable peptides induce dose- and length-dependent cytotoxic effects. Biochim. Biophys. Acta 2007, 1768, 2222-2234. [CrossRef] [PubMed]

24. Fields, J.A.; Dumaop, W.; Crews, L.; Adame, A.; Spencer, B.; Metcalf, J.; He, J.; Rockenstein, E.; Masliah, E. Mechanisms of HIV-1 Tat neurotoxicity via CDK5 translocation and hyper-activation: Role in HIV-associated neurocognitive disorders. Curr. HIV Res. 2015, 13, 43-54. [CrossRef] [PubMed]

25. Bagashev, A.; Sawaya, B.E. Roles and functions of HIV-1 Tat protein in the CNS: An overview. Virol. J. 2013, 10, 358. [CrossRef] [PubMed]

26. Mi, Q.; Yao, G.; Zhang, G.Y.; Zhang, J.; Wang, J.; Zhao, P.; Liu, J. Disruption of GluR2/GAPDH Complex Interaction by TAT-GluR2NT1-3-2 Peptide Protects against Neuronal Death Induced by Epilepsy. Ann. Clin. Lab. Sci. 2018, 48, 460-468.

27. Rizzuti, M.; Nizzardo, M.; Zanetta, C.; Ramirez, A.; Corti, S. Therapeutic applications of the cell-penetrating HIV-1 Tat peptide. Drug Discov. Today 2015, 20, 76-85. [CrossRef]

28. Meloni, B.P.; Milani, D.; Cross, J.L.; Clark, V.W.; Edwards, A.B.; Anderton, R.S.; Blacker, D.J.; Knuckey, N.W. Assessment of the Neuroprotective Effects of Arginine-Rich Protamine Peptides, Poly-Arginine Peptides (R12-Cyclic, R22) and ArginineTryptophan-Containing Peptides Following In Vitro Excitotoxicity and/or Permanent Middle Cerebral Artery Occlusion in Rats. Neuromolecular Med. 2017, 19, 271-285. [CrossRef]

29. Peng, J.; Rao, Y.; Yang, X.; Jia, J.; Wu, Y.; Lu, J.; Tao, Y.; Tu, W. Targeting neuronal nitric oxide synthase by a cell penetrating peptide Tat-LK15/siRNA bioconjugate. Neurosci. Lett. 2017, 650, 153-160. [CrossRef]

30. Galdiero, S.; Falanga, A.; Cantisani, M.; Vitiello, M.; Morelli, G.; Galdiero, M. Peptide-lipid interactions: Experiments and applications. Int. J. Mol. Sci. 2013, 14, 18758-18789. [CrossRef]

31. MacDougall, G.; Anderton, R.S.; Edwards, A.B.; Knuckey, N.W.; Meloni, B.P. The Neuroprotective Peptide Poly-Arginine-12 (R12) Reduces Cell Surface Levels of NMDA NR2B Receptor Subunit in Cortical Neurons; Investigation into the Involvement of Endocytic Mechanisms. J. Mol. Neurosci. 2017, 61, 235-246. [CrossRef] [PubMed]

32. Holloway, P.M.; Gavins, F.N. Modeling Ischemic Stroke In Vitro: Status Quo and Future Perspectives. Stroke 2016, 47, 561-569. [CrossRef] [PubMed]

33. Eigenmann, D.E.; Xue, G.; Kim, K.S.; Moses, A.V.; Hamburger, M.; Oufir, M. Comparative study of four immortalized human brain capillary endothelial cell lines, hCMEC/D3, hBMEC, TY10, and BB19, and optimization of culture conditions, for an in vitro blood-brain barrier model for drug permeability studies. Fluids Barriers CNS 2013, 10, 33. [CrossRef] [PubMed] 
34. Al Ahmad, A.; Taboada, C.B.; Gassmann, M.; Ogunshola, O.O. Astrocytes and pericytes differentially modulate blood-brain barrier characteristics during development and hypoxic insult. J. Cereb. Blood Flow Metab. Off. J. Int. Soc. Cereb. Blood Flow Metab. 2011, 31, 693-705. [CrossRef] [PubMed]

35. Tilling, T.; Korte, D.; Hoheisel, D.; Galla, H.J. Basement membrane proteins influence brain capillary endothelial barrier function in vitro. J. Neurochem. 1998, 71, 1151-1157. [CrossRef]

36. Zhang, W.; Smith, C.; Howlett, C.; Stanimirovic, D. Inflammatory activation of human brain endothelial cells by hypoxic astrocytes in vitro is mediated by IL-1beta. J. Cereb. Blood Flow Metab. 2000, 20, 967-978. [CrossRef]

37. Haile, Y.; Fu, W.; Shi, B.; Westaway, D.; Baker, G.; Jhamandas, J.; Giuliani, F. Characterization of the NT2-derived neuronal and astrocytic cell lines as alternative in vitro models for primary human neurons and astrocytes. J. Neurosci. Res. 2014, 92, 1187-1198 [CrossRef]

38. Selvaraj, V.; Jiang, P.; Chechneva, O.; Lo, U.G.; Deng, W. Differentiating human stem cells into neurons and glial cells for neural repair. Front Biosci. 2012, 17, 65-89. [CrossRef]

39. Durnaoglu, S.; Genc, S.; Genc, K. Patient-specific pluripotent stem cells in neurological diseases. Stem Cells Int. 2011, $2011,212487$. [CrossRef]

40. Amemori, T.; Romanyuk, N.; Jendelova, P.; Herynek, V.; Turnovcova, K.; Prochazka, P.; Kapcalova, M.; Cocks, G.; Price, J.; Sykova, E. Human conditionally immortalized neural stem cells improve locomotor function after spinal cord injury in the rat. Stem Cell Res. Ther. 2013, 4, 68. [CrossRef]

41. Peretz, H.; Talpalar, A.E.; Vago, R.; Baranes, D. Superior survival and durability of neurons and astrocytes on 3-dimensional aragonite biomatrices. Tissue Eng. 2007, 13, 461-472. [CrossRef]

42. Taylor, A.M.; Blurton-Jones, M.; Rhee, S.W.; Cribbs, D.H.; Cotman, C.W.; Jeon, N.L. A microfluidic culture platform for CNS axonal injury, regeneration and transport. Nat. Methods 2005, 2, 599-605. [CrossRef] [PubMed]

43. Antonic, A.; Sena, E.S.; Donnan, G.A.; Howells, D.W. Human in vitro models of ischaemic stroke: A test bed for translation. Transl. Stroke Res. 2012, 3, 306-309. [CrossRef] [PubMed]

44. Kalafatovic, D.; Giralt, E. Cell-Penetrating Peptides: Design Strategies beyond Primary Structure and Amphipathicity. Molecules 2017, 22, 1929. [CrossRef] [PubMed]

45. Szyk, A.; Mucha, P.; Rekowski, P.; Giel-Pietraszuk, M.; Barciszewski, J. Synthesis and circular dichroism studies of HIV-1 Tat arginine rich domain analogues substituted in Arg 52 position. Pol. J. Chem. 1999, 73, 879-883.

46. Ruzza, P.; Biondi, B.; Marchiani, A.; Antolini, N.; Calderan, A. Cell-Penetrating Peptides: A Comparative Study on Lipid Affinity and Cargo Delivery Properties. Pharmaceuticals 2010, 3, 1045-1062. [CrossRef]

47. Ruzza, P.; Calderan, A.; Guiotto, A.; Osler, A.; Borin, G. Tat cell-penetrating peptide has the characteristics of a poly(proline) II helix in aqueous solution and in SDS micelles. J. Pept. Sci. Off. Publ. Eur. Pept. Soc. 2004, 10, 423-426. [CrossRef]

48. Lam, S.L.; Hsu, V.L. NMR identification of left-handed polyproline type II helices. Biopolymers 2003, 69, 270-281. [CrossRef]

49. Roccatano, D.; Colombo, G.; Fioroni, M.; Mark, A.E. Mechanism by which 2,2,2-trifluoroethanol/water mixtures stabilize secondary-structure formation in peptides: A molecular dynamics study. Proc. Natl. Acad. Sci. USA 2002, 99, 12179-12184. [CrossRef]

50. Diaz, M.D.; Fioroni, M.; Burger, K.; Berger, S. Evidence of complete hydrophobic coating of bombesin by trifluoroethanol in aqueous solution: An NMR spectroscopic and molecular dynamics study. Chemistry 2002, 8, 1663-1669. [CrossRef]

51. Fort, A.G.; Spray, D.C. Trifluoroethanol reveals helical propensity at analogous positions in cytoplasmic domains of three connexins. Biopolymers 2009, 92, 173-182. [CrossRef] [PubMed]

52. Luo, P.; Baldwin, R.L. Mechanism of helix induction by trifluoroethanol: A framework for extrapolating the helix-forming properties of peptides from trifluoroethanol/water mixtures back to water. Biochemistry 1997, 36, 8413-8421. [CrossRef]

53. Krimm, S.; Mark, J.E. Conformations of polypeptides with ionized side chains of equal length. Proc. Natl. Acad. Sci. USA 1968, 60, 1122-1129. [CrossRef] [PubMed]

54. Holzwarth, G.; Doty, P. The Ultraviolet Circular Dichroism of Polypeptides. J. Am. Chem. Soc. 1965, 87, 218-228. [CrossRef]

55. Edwards, A.B.; Anderton, R.S.; Knuckey, N.W.; Meloni, B.P. Characterisation of neuroprotective efficacy of modified polyarginine-9 (R9) peptides using a neuronal glutamic acid excitotoxicity model. Mol. Cell. Biochem. 2017, 426, 75-85. [CrossRef] [PubMed]

56. Wang, G. Post-translational Modifications of Natural Antimicrobial Peptides and Strategies for Peptide Engineering. Curr. Biotechnol. 2012, 1, 72-79. [CrossRef]

57. Yamada, T.; Signorelli, S.; Cannistraro, S.; Beattie, C.W.; Bizzarri, A.R. Chirality switching within an anionic cell-penetrating peptide inhibits translocation without affecting preferential entry. Mol. Pharm. 2015, 12, 140-149. [CrossRef] [PubMed]

58. Pujals, S.; Sabido, E.; Tarrago, T.; Giralt, E. all-D proline-rich cell-penetrating peptides: A preliminary in vivo internalization study. Biochem. Soc. Trans. 2007, 35, 794-796. [CrossRef] [PubMed]

59. Verdurmen, W.P.; Bovee-Geurts, P.H.; Wadhwani, P.; Ulrich, A.S.; Hallbrink, M.; van Kuppevelt, T.H.; Brock, R. Preferential uptake of L- versus D-amino acid cell-penetrating peptides in a cell type-dependent manner. Chem. Biol. 2011, 18, 1000-1010. [CrossRef]

60. Ma, Y.; Gong, C.; Ma, Y.; Fan, F.; Luo, M.; Yang, F.; Zhang, Y.H. Direct cytosolic delivery of cargoes in vivo by a chimera consisting of D- and L-arginine residues. J. Control. Release Off. J. Control. Release Soc. 2012, 162, 286-294. [CrossRef] 
61. Som, A.; Tezgel, A.O.; Gabriel, G.J.; Tew, G.N. Self-activation in de novo designed mimics of cell-penetrating peptides. Angew. Chem. 2011, 50, 6147-6150. [CrossRef] [PubMed]

62. Som, A.; Reuter, A.; Tew, G.N. Protein transduction domain mimics: The role of aromatic functionality. Angew. Chem. 2012, 51, 980-983. [CrossRef] [PubMed]

63. Terrasso, A.P.; Silva, A.C.; Filipe, A.; Pedroso, P.; Ferreira, A.L.; Alves, P.M.; Brito, C. Human neuron-astrocyte 3D co-culture-based assay for evaluation of neuroprotective compounds. J. Pharmacol. Toxicol. Methods 2017, 83, 72-79. [CrossRef]

64. Jiang, D.; Gao, T.; Liang, S.; Mu, W.; Fu, S.; Liu, Y.; Yang, R.; Zhang, Z.; Liu, Y.; Zhang, N. Lymph Node Delivery Strategy Enables the Activation of Cytotoxic T Lymphocytes and Natural Killer Cells to Augment Cancer Immunotherapy. ACS Appl. Mater. Interfaces 2021, 13, 22213-22224. [CrossRef] [PubMed]

65. Kumar, N.; Afjei, R.; Massoud, T.F.; Paulmurugan, R. Comparison of cell-based assays to quantify treatment effects of anticancer drugs identifies a new application for Bodipy-L-cystine to measure apoptosis. Sci. Rep. 2018, 8, 16363. [CrossRef] [PubMed]

66. Rai, Y.; Pathak, R.; Kumari, N.; Sah, D.K.; Pandey, S.; Kalra, N.; Soni, R.; Dwarakanath, B.S.; Bhatt, A.N. Mitochondrial biogenesis and metabolic hyperactivation limits the application of MTT assay in the estimation of radiation induced growth inhibition. Sci. Rep. 2018, 8, 1531. [CrossRef]

67. Takahashi, S.; Abe, T.; Gotoh, J.; Fukuuchi, Y. Substrate-dependence of reduction of MTT: A tetrazolium dye differs in cultured astroglia and neurons. Neurochem. Int. 2002, 40,441-448. [CrossRef]

68. Brouillet, E.; Hyman, B.T.; Jenkins, B.G.; Henshaw, D.R.; Schulz, J.B.; Sodhi, P.; Rosen, B.R.; Beal, M.F. Systemic or local administration of azide produces striatal lesions by an energy impairment-induced excitotoxic mechanism. Exp. Neurol. 1994, 129, 175-182. [CrossRef]

69. Gao, C.; Chang, P.; Yang, L.; Wang, Y.; Zhu, S.; Shan, H.; Zhang, M.; Tao, L. Neuroprotective effects of hydrogen sulfide on sodium azide-induced oxidative stress in PC12 cells. Int. J. Mol. Med. 2018, 41, 242-250. [CrossRef]

70. Knyihar-Csillik, E.; Okuno, E.; Vecsei, L. Effects of in vivo sodium azide administration on the immunohistochemical localization of kynurenine aminotransferase in the rat brain. Neuroscience 1999, 94, 269-277. [CrossRef]

71. Jaiswal, M.K. Riluzole But Not Melatonin Ameliorates Acute Motor Neuron Degeneration and Moderately Inhibits SOD1Mediated Excitotoxicity Induced Disrupted Mitochondrial $\mathrm{Ca}^{2+}$ Signaling in Amyotrophic Lateral Sclerosis. Front. Cell. Neurosci. 2016, 10, 295. [CrossRef]

72. Xiang, Z.; Yuan, M.; Hassen, G.W.; Gampel, M.; Bergold, P.J. Lactate induced excitotoxicity in hippocampal slice cultures. Exp. Neurol. 2004, 186, 70-77. [CrossRef] [PubMed]

73. Khan, N.A.; Guevara, P.; Sotelo, J. Influence of in vitro lactic acidosis on central nervous system neurons. Pathol. Biol. 1989, 37, 725-729.

74. Goldman, S.A.; Pulsinelli, W.A.; Clarke, W.Y.; Kraig, R.P.; Plum, F. The effects of extracellular acidosis on neurons and glia in vitro. J. Cereb. Blood Flow Metab. 1989, 9, 471-477. [CrossRef] [PubMed]

75. Meade, A.J.; Meloni, B.P.; Mastaglia, F.L.; Watt, P.M.; Knuckey, N.W. AP-1 inhibitory peptides attenuate in vitro cortical neuronal cell death induced by kainic acid. Brain Res. 2010, 1360, 8-16. [CrossRef]

76. Lariosa-Willingham, K.D.; Rosler, E.S.; Tung, J.S.; Dugas, J.C.; Collins, T.L.; Leonoudakis, D. A high throughput drug screening assay to identify compounds that promote oligodendrocyte differentiation using acutely dissociated and purified oligodendrocyte precursor cells. BMC Res. Notes 2016, 9, 419. [CrossRef] [PubMed]

77. Gupta, A.; Gautam, P.; Wennerberg, K.; Aittokallio, T. A normalized drug response metric improves accuracy and consistency of anticancer drug sensitivity quantification in cell-based screening. Commun. Biol. 2020, 3, 42. [CrossRef]

78. Owens, B. Stroke. Nature 2014, 510, S1. [CrossRef]

79. Venkat, P.; Shen, Y.; Chopp, M.; Chen, J. Cell-based and pharmacological neurorestorative therapies for ischemic stroke. Neuropharmacology 2018, 134, 310-322. [CrossRef]

80. Chandra, A.; Stone, C.R.; Du, X.; Li, W.A.; Huber, M.; Bremer, R.; Geng, X.; Ding, Y. The cerebral circulation and cerebrovascular disease III: Stroke. Brain Circ. 2017, 3, 66-77.

81. Xu, J.K.; Khan, A.R.; Fu, M.F.; Wang, R.J.; Ji, J.B.; Zhai, G.X. Cell-penetrating peptide: A means of breaking through the physiological barriers of different tissues and organs. J. Control. Release 2019, 309, 106-124. [CrossRef]

82. Meng, T.; Cao, Q.; Lei, P.; Bush, A.I.; Xiang, Q.; Su, Z.; He, X.; Rogers, J.T.; Chiu, I.M.; Zhang, Q.; et al. Tat-haFGF14-154 Upregulates ADAM10 to Attenuate the Alzheimer Phenotype of APP/PS1 Mice through the PI3K-CREB-IRE1alpha/XBP1 Pathway. Mol. Ther. Nucleic Acids 2017, 7, 439-452. [CrossRef] [PubMed]

83. Edwards, A.B.; Cross, J.L.; Anderton, R.S.; Knuckey, N.W.; Meloni, B.P. Poly-arginine R18 and R18D (D-enantiomer) peptides reduce infarct volume and improves behavioural outcomes following perinatal hypoxic-ischaemic encephalopathy in the P7 rat. Mol. Brain 2018, 11, 8. [CrossRef]

84. Chassagnon, I.R.; McCarthy, C.A.; Chin, Y.K.; Pineda, S.S.; Keramidas, A.; Mobli, M.; Pham, V.; De Silva, T.M.; Lynch, J.W.; Widdop, R.E.; et al. Potent neuroprotection after stroke afforded by a double-knot spider-venom peptide that inhibits acid-sensing ion channel 1a. Proc. Natl. Acad. Sci. USA 2017, 114, 3750-3755. [CrossRef]

85. Hu, X.T. HIV-1 Tat-Mediated Calcium Dysregulation and Neuronal Dysfunction in Vulnerable Brain Regions. Curr. Drug Targets 2016, 17, 4-14. [CrossRef] [PubMed]

86. Kaul, M.; Garden, G.A.; Lipton, S.A. Pathways to neuronal injury and apoptosis in HIV-associated dementia. Nature 2001, 410, 988-994. [CrossRef] 
87. Haughey, N.J.; Nath, A.; Mattson, M.P.; Slevin, J.T.; Geiger, J.D. HIV-1 Tat through phosphorylation of NMDA receptors potentiates glutamate excitotoxicity. J. Neurochem. 2001, 78, 457-467. [CrossRef]

88. Valcour, V.; Shiramizu, B. HIV-associated dementia, mitochondrial dysfunction, and oxidative stress. Mitochondrion 2004, 4, 119-129. [CrossRef]

89. Heaton, R.K.; Clifford, D.B.; Franklin, D.R., Jr.; Woods, S.P.; Ake, C.; Vaida, F.; Ellis, R.J.; Letendre, S.L.; Marcotte, T.D.; Atkinson, J.H.; et al. HIV-associated neurocognitive disorders persist in the era of potent antiretroviral therapy: Charter Study. Neurology 2010, 75, 2087-2096. [CrossRef]

90. Chiu, L.S.; Anderton, R.S.; Cross, J.L.; Clark, V.W.; Edwards, A.B.; Knuckey, N.W.; Meloni, B.P. Assessment of R18, COG1410, and APP96-110 in Excitotoxicity and Traumatic Brain Injury. Transl. Neurosci. 2017, 8, 147-157. [CrossRef]

91. Di Menna, L.; Molinaro, G.; Di Nuzzo, L.; Riozzi, B.; Zappulla, C.; Pozzilli, C.; Turrini, R.; Caraci, F.; Copani, A.; Battaglia, G.; et al Fingolimod protects cultured cortical neurons against excitotoxic death. Pharmacol. Res. 2013, 67, 1-9. [CrossRef]

92. Cipriani, R.; Chara, J.C.; Rodriguez-Antiguedad, A.; Matute, C. FTY720 attenuates excitotoxicity and neuroinflammation. J. Neuroinflammation 2015, 12, 86. [CrossRef]

93. De Hemptinne, A.; Marrannes, R.; Vanheel, B. Influence of organic acids on intracellular pH. Am. J. Physiol. 1983, 245, C178-C183. [CrossRef]

94. Baumann, F.; Leukel, P.; Doerfelt, A.; Beier, C.P.; Dettmer, K.; Oefner, P.J.; Kastenberger, M.; Kreutz, M.; Nickl-Jockschat, T.; Bogdahn, U.; et al. Lactate promotes glioma migration by TGF-beta2-dependent regulation of matrix metalloproteinase-2. Neuro Oncol. 2009, 11, 368-380. [CrossRef]

95. Li, X.; Yu, X.; Dai, D.; Song, X.; Xu, W. The altered glucose metabolism in tumor and a tumor acidic microenvironment associated with extracellular matrix metalloproteinase inducer and monocarboxylate transporters. Oncotarget 2016, 7, 2314123155. [CrossRef]

96. Chen, F.Y.; Lee, T.J. Arginine synthesis from citrulline in perivascular nerves of cerebral artery. J. Pharmacol. Exp. Ther. 1995, 273, 895-901. [PubMed]

97. Wang, T.Y.; Sun, Y.; Muthukrishnan, N.; Erazo-Oliveras, A.; Najjar, K.; Pellois, J.P. Membrane Oxidation Enables the Cytosolic Entry of Polyarginine Cell-penetrating Peptides. J. Biol. Chem. 2016, 291, 7902-7914. [CrossRef]

98. Cerrato, C.P.; Pirisinu, M.; Vlachos, E.N.; Langel, U. Novel cell-penetrating peptide targeting mitochondria. FASEB J. 2015, 29, 4589-4599. [CrossRef]

99. Ziegler, A.; Seelig, J. Interaction of the protein transduction domain of HIV-1 TAT with heparan sulfate: Binding mechanism and thermodynamic parameters. Biophys. J. 2004, 86, 254-263. [CrossRef]

100. Youn, J.I.; Park, S.H.; Jin, H.T.; Lee, C.G.; Seo, S.H.; Song, M.Y.; Lee, C.W.; Sung, Y.C. Enhanced delivery efficiency of recombinant adenovirus into tumor and mesenchymal stem cells by a novel PTD. Cancer Gene Ther. 2008, 15, 703-712. [CrossRef]

101. Hill, M.D.; Goyal, M.; Menon, B.K.; Nogueira, R.G.; McTaggart, R.A.; Demchuk, A.M.; Poppe, A.Y.; Buck, B.H.; Field, T.S.; Dowlatshahi, D.; et al. Efficacy and safety of nerinetide for the treatment of acute ischaemic stroke (ESCAPE-NA1): A multicentre, double-blind, randomised controlled trial. Lancet 2020, 395, 878-887. [CrossRef]

102. Zhu, Y.; Bu, Q.; Liu, X.; Hu, W.; Wang, Y. Neuroprotective effect of TAT-14-3-3epsilon fusion protein against cerebral ischemia/reperfusion injury in rats. PLoS ONE 2014, 9, e93334.

103. Tu, J.; Zhang, X.; Zhu, Y.; Dai, Y.; Li, N.; Yang, F.; Zhang, Q.; Brann, D.W.; Wang, R. Cell-Permeable Peptide Targeting the Nrf2-Keap1 Interaction: A Potential Novel Therapy for Global Cerebral Ischemia. J. Neurosci. 2015, 35, 14727-14739. [CrossRef]

104. Cao, G.; Pei, W.; Ge, H.; Liang, Q.; Luo, Y.; Sharp, F.R.; Lu, A.; Ran, R.; Graham, S.H.; Chen, J. In Vivo Delivery of a Bcl-xL Fusion Protein Containing the TAT Protein Transduction Domain Protects against Ischemic Brain Injury and Neuronal Apoptosis. J. Neurosci. 2002, 22, 5423-5431. [CrossRef] [PubMed]

105. Kilic, E.; Kilic, U.; Hermann, D.M. TAT-GDNF in neurodegeneration and ischemic stroke. CNS Drug Rev. 2005, 11, 369-378. [CrossRef]

106. Doeppner, T.R.; Kaltwasser, B.; Fengyan, J.; Hermann, D.M.; Bahr, M. TAT-Hsp70 induces neuroprotection against stroke via anti-inflammatory actions providing appropriate cellular microenvironment for transplantation of neural precursor cells. J. Cereb. Blood Flow Metab. 2013, 33, 1778-1788. [CrossRef]

107. Kilic, U.; Kilic, E.; Dietz, G.P.; Bahr, M. The TAT protein transduction domain enhances the neuroprotective effect of glial-cell-linederived neurotrophic factor after optic nerve transection. Neuro Degener. Dis. 2004, 1, 44-49. [CrossRef]

108. Pei, D.S.; Wang, X.T.; Liu, Y.; Sun, Y.F.; Guan, Q.H.; Wang, W.; Yan, J.Z.; Zong, Y.Y.; Xu, T.L.; Zhang, G.Y. Neuroprotection against ischaemic brain injury by a GluR6-9c peptide containing the TAT protein transduction sequence. Brain 2006, 129, 465-479. [CrossRef] [PubMed]

109. Popiel, H.A.; Nagai, Y.; Fujikake, N.; Toda, T. Protein transduction domain-mediated delivery of QBP1 suppresses polyglutamineinduced neurodegeneration in vivo. Mol. Ther. J. Am. Soc. Gene Ther. 2007, 15, 303-309. [CrossRef]

110. Madani, F.; Lindberg, S.; Langel, U.; Futaki, S.; Graslund, A. Mechanisms of cellular uptake of cell-penetrating peptides. J. Biophys. 2011, 2011, 414729. [CrossRef] [PubMed]

111. Herve, F.; Ghinea, N.; Scherrmann, J.M. CNS delivery via adsorptive transcytosis. AAPS J. 2008, 10, 455-472. [CrossRef]

112. Meloni, B.P.; Mastaglia, F.L.; Knuckey, N.W. Cationic Arginine-Rich Peptides (CARPs): A Novel Class of Neuroprotective Agents with a Multimodal Mechanism of Action. Front Neurol 2020, 11, 108. [CrossRef] [PubMed] 
113. Rao, Y.; Kwok, S.J.; Lombardi, J.; Turro, N.J.; Eisenthal, K.B. Label-free probe of HIV-1 TAT peptide binding to mimetic membranes. Proc. Natl. Acad. Sci. USA 2014, 111, 12684-12688. [CrossRef]

114. Chiu, L.S.; Anderton, R.S.; Knuckey, N.W.; Meloni, B.P. The neuroprotective potential of arginine-rich peptides for the acute treatment of traumatic brain injury. Expert Rev. Neurother. 2016, 16, 361-363. [CrossRef] [PubMed]

115. Lorents, A.; Kodavali, P.K.; Oskolkov, N.; Langel, U.; Hallbrink, M.; Pooga, M. Cell-penetrating Peptides Split into Two Groups Based on Modulation of Intracellular Calcium Concentration. J. Biol. Chem. 2012, 287, 16880-16889. [CrossRef] [PubMed]

116. Nath, A.; Psooy, K.; Martin, C.; Knudsen, B.; Magnuson, D.S.K.; Haughey, N.; Geiger, J.D. Identification of a human immunodeficiency virus type 1 tat epitope that is neuroexcitatory and neurotoxic. J. Virol. 1996, 70, 1475-1480. [CrossRef]

117. Ramos-Molina, B.; Lick, A.N.; Nasrolahi Shirazi, A.; Oh, D.; Tiwari, R.; El-Sayed, N.S.; Parang, K.; Lindberg, I. Cationic Cell-Penetrating Peptides Are Potent Furin Inhibitors. PLoS ONE 2015, 10, e0130417. [CrossRef]

118. Case, D.A.; Cheatham, T.E.; Darden, T.; Gohlke, H.; Luo, R.; Merz, K.M.; Onufriev, A.; Simmerling, C.; Wang, B.; Woods, R.J. The Amber biomolecular simulation programs. J. Comput. Chem. 2005, 26, 1668-1688. [CrossRef]

119. Debiec, K.T.; Cerutti, D.S.; Baker, L.R.; Gronenborn, A.M.; Case, D.A.; Chong, L.T. Further along the Road Less Traveled: AMBER ff15ipq, an Original Protein Force Field Built on a Self-Consistent Physical Model. J. Chem. Theory Comput. 2016, 12, 3926-3947. [CrossRef]

120. Tsui, V.; Case, D.A. Theory and applications of the generalized Born solvation model in macromolecular simulations. Biopolymers 2000, 56, 275-291. [CrossRef]

121. Roe, D.R.; Cheatham, T.E., 3rd. PTRAJ and CPPTRAJ: Software for Processing and Analysis of Molecular Dynamics Trajectory Data. J. Chem. Theory Comput. 2013, 9, 3084-3095. [CrossRef]

122. Koradi, R.; Billeter, M.; Wuthrich, K. MOLMOL: A program for display and analysis of macromolecular structures. J. Mol. Graph. 1996, 14, 51-55. [CrossRef] 